\title{
Hydrogeochemical Characterization of a Warm Spring System in a Carbonate Mountain Range of the Eastern Julian Alps, Slovenia
}

\author{
Luka Serianz $^{1, *}$, Nina Rman ${ }^{1}$ [D and Mihael Brenčič ${ }^{2}$ \\ 1 Geological Survey of Slovenia, 1000 Ljubljana, Slovenia; nina.rman@geo-zs.si \\ 2 Faculty of Natural Sciences and Engineering, University of Ljubljana, 1000 Ljubljana, Slovenia; \\ mihael.brencic@geo.ntf.uni-lj.si \\ * Correspondence: luka.serianz@geo-zs.si; Tel.: +386-(0)1-2809-792
}

Received: 18 April 2020; Accepted: 11 May 2020; Published: 17 May 2020

check for updates

\begin{abstract}
The Alps represent an area where many deep groundwater circulations occur as thermal springs. In the Bled case study, the thermal water temperature, at it is discharged to the surface, is between $19-23^{\circ} \mathrm{C}$. In order to determine the extent (e.g., geometry) and the origin of the pronounced deep circulation system in the Bled area, chemical and isotopic measurements of waters from different hydrogeological systems were performed (e.g., surface water, thermal water, fresh groundwater). Hydrogeochemical methods were used to tie together the above-mentioned parameters. The results have shown that thermal outflow in Bled is determined by the presence of a deep-water circulation system, where the dissolution of carbonates minerals is the main hydrogeochemical process affecting chemical components of natural water flow. The correlation of the major ions suggests that the recharge area is represented by both limestone and dolomite rocks. Moreover, the results of $\delta^{18} \mathrm{O}$ and $\delta^{2} \mathrm{H}$ of all samples indicate that the recharge is mainly meteoric precipitation. The recharge altitude was estimated for two sampled fresh groundwater springs. The isotopic compositions of those two springs suggest the range from $\delta^{18} \mathrm{O}=-8.68 \%, \delta^{2} \mathrm{H}=-57.4 \%$ o at an elevation of $629 \mathrm{~m}$ to $\delta^{18} \mathrm{O}=-9.30 \%$ o, $\delta^{2} \mathrm{H}=-60.1 \%$ at an elevation of $1216 \mathrm{~m}$. The isotopic analysis has confirmed that the thermal water recharges from altitudes of 1282-1620 $\mathrm{m}$ a.s.l.
\end{abstract}

Keywords: thermal spring; groundwater; hydrogeochemical characteristics; stable isotopes; Julian Alps

\section{Introduction}

It is well known that the thermal flow regime in regional groundwater systems is affected by local as well as regional hydrogeological conditions, hydraulics, geology, geomorphology, topography, and recharge area characteristics [1-3]. The convective low temperature geothermal systems are characterized by high porosity, high permeability, and by deep natural circulation of the working fluid related to meteoric infiltration [4]. These systems are also classified as a warm spring system and can often be found in foothill regions of mountainous terrain, even within mountain valleys [5]. The Alpine mountain range is one of the major areas in Europe where many such systems occur as thermal springs [6]. Those are usually driven by topography-induced differences in hydraulic potential. Knowledge about the spatial extent (geometry) and intensity (flow velocity/flow rate) of deep circulation systems is essential for decision making in the development and protection of such thermal water resources [7]. Higher temperature in such systems is not due to the existence of a heat flow anomaly [8] but results from deep flow through permeable faults or subvertical strata [9-12]. The outflow of thermal fluid is limited by specific hydrogeological conditions (e.g., the presence of 
a fault zone), which indicates the typical free and forced derived convection flow. When the water is uprising due to convection, it is very likely that the mixing processes between the deep thermal component and cold shallow groundwater are established. Two cases are possible: (1) Mixing with fresh groundwater from the shallower zone of a karstic-fissured aquifer; and (2) mixing with fresh groundwater from a porous shallow aquifer. Thermal water discharges inside the Quaternary shallow porous deposits, forming a thermal plume, which is not noticeable without boreholes.

In Slovenia, three types of low temperature geothermal systems prevail: (1) Geothermal systems with aquifers in the basement of sedimentary basins and with fissured porosity; (2) geothermal systems with aquifers in sedimentary basins and of intergranular porosity; and (3) geothermal systems with warm springs and fissure porosity [13]. The occurrence of the latter is indicated by thermal springs which are mainly recharged by carbonate rocks resulting in only moderate mineralization of thermal water $[13,14]$. Such systems can be found in the Julian Alps, but only two locations are known, Bled and Zatolmin $[13,15-17]$. In this paper, we focused on the Bled case study, which is a most prominent case of the pronounced geothermal system with warm springs in Slovenia.

Hydrogeochemical methods are an important way within the geothermal resources assessment to obtain information, such as geothermal fluid origin, circulation paths, residence time, mixing processes, water-rock interactions, reservoir rock characteristics, and reservoir temperature [18-20]. Natural and anthropogenic tracers have been extensively used to determine both local and regional water flow patterns [21,22]. In carbonate reservoirs, the main chemical parameters that describe the groundwater carbonate equilibrium are calcium $\left(\mathrm{Ca}^{2+}\right)$, magnesium $\left(\mathrm{Mg}^{2+}\right)$, their molar ratio $\left(\mathrm{Ca}^{2+} / \mathrm{Mg}^{2+}\right)$, and hydrogen carbonate $\left(\mathrm{HCO}_{3}{ }^{-}\right)$. In addition, chloride $\left(\mathrm{Cl}^{-}\right)$, boron $\left(\mathrm{B}^{3+}\right)$, barium $\left(\mathrm{Ba}^{2+}\right)$, and strontium $\left(\mathrm{Sr}^{2+}\right)$ display conservative behavior and can therefore also be used as tracers, also in geothermal systems $[23,24]$. Besides chemical parameters, stable isotopes of oxygen $\left(\delta^{18} \mathrm{O}\right)$ and hydrogen $\left(\delta^{2} \mathrm{H}\right)$ in water can also provide information about the recharge areas [25,26], while tritium activity provides information about an average groundwater retention time. A combination of chemical, stable, and radioactive isotope data has often been used for hydrogeological research of thermal and mineral waters, and the same techniques have also been applied in Slovenia $[24,27,28]$. More and more often, new parameters are being enchanted such as ${ }^{87} \mathrm{Sr} /{ }^{86} \mathrm{Sr}$ and $\delta^{11} \mathrm{~B}$ [29]. Although there have been several regional hydrogeochemical investigations of groundwater performed in the last decade also focused on carbonates [30-34], the published analyses of thermal water are rather sparse. A general overview of Slovenian thermal waters' chemical composition was published in [14].

In Bled, the first systematic research was performed in the second half of the 20th century when intensive drilling activities took place. There were 16 boreholes drilled in the thermal spring area, but today (in 2020) only 5 of them exist, including the latest well VB-2/04, which was drilled in 2004. The deepest reaching depth was $587.6 \mathrm{~m}$. Those reports are not published but are archived at the Geological Survey of Slovenia. After the exploitation site got water concession in 2015 for the use of thermal water from two wells and one thermal spring, intended for the heating and bathing of Sava Hotels Bled, operational monitoring was established, providing hourly water level, temperature, and discharge data, as well as annual chemical and isotopic composition of waters. Hydrogeochemical information on the surroundings were focused mostly on the characterization of the Radovna River and its springs $[33,35]$.

In order to understand the dynamics of Alpine low-temperature geothermal systems, it is necessary to develop a conceptual model. In this paper we focused on the hydrogeochemical characterization of thermal water with discussion about its origin, e.g., recharge area, mixing processes with cold water, and other physically derived flow patterns in the study area of Bled, Slovenia. 


\section{Study Area Settings}

\subsection{Geographical Settings}

The investigated area is located in NW Slovenia, in the Eastern Julian Alps (Figure 1). It is surrounded by three alpine karstic plateaus-Jelovica (south), Pokljuka (west), and Mežakla (north). The altitude of the Jelovica plateau is between 900 and $1411 \mathrm{~m}$. The altitude of the Pokljuka plateau is between 852 and $1630 \mathrm{~m}$, while in the north-western part of the plateau, the altitudes in the surrounding terrain rise to $2200 \mathrm{~m}$ [35,36]. The Mežakla plateau has altitudes between 776 and $1593 \mathrm{~m}$. All three plateaus are covered with forest and surrounded by steep slopes, up to a few $100 \mathrm{~m} \mathrm{high}$. The mountainous plateaus were sculped by glaciers in the Pleistocene and formed two alpine valleys in between the Bohinj Valley and the Radovna River valley. At the observation area there is glacial lake named Lake Bled. The depth of the lake is up to approx. $30 \mathrm{~m}$. The main outflow from the lake is the Jezernica Stream, which flows into Sava Bohinjka. The only town is Bled, while other surrounding settlements are villages. The alpine plateaus represent an important part of the watershed area, for both Sava Bohinjka and Radovna River. Both are typical alpine rivers, discharging into the Sava River. The thermal water outflow is located at the eastern side of the Lake Bled, where it is exploited for heating and bathing.

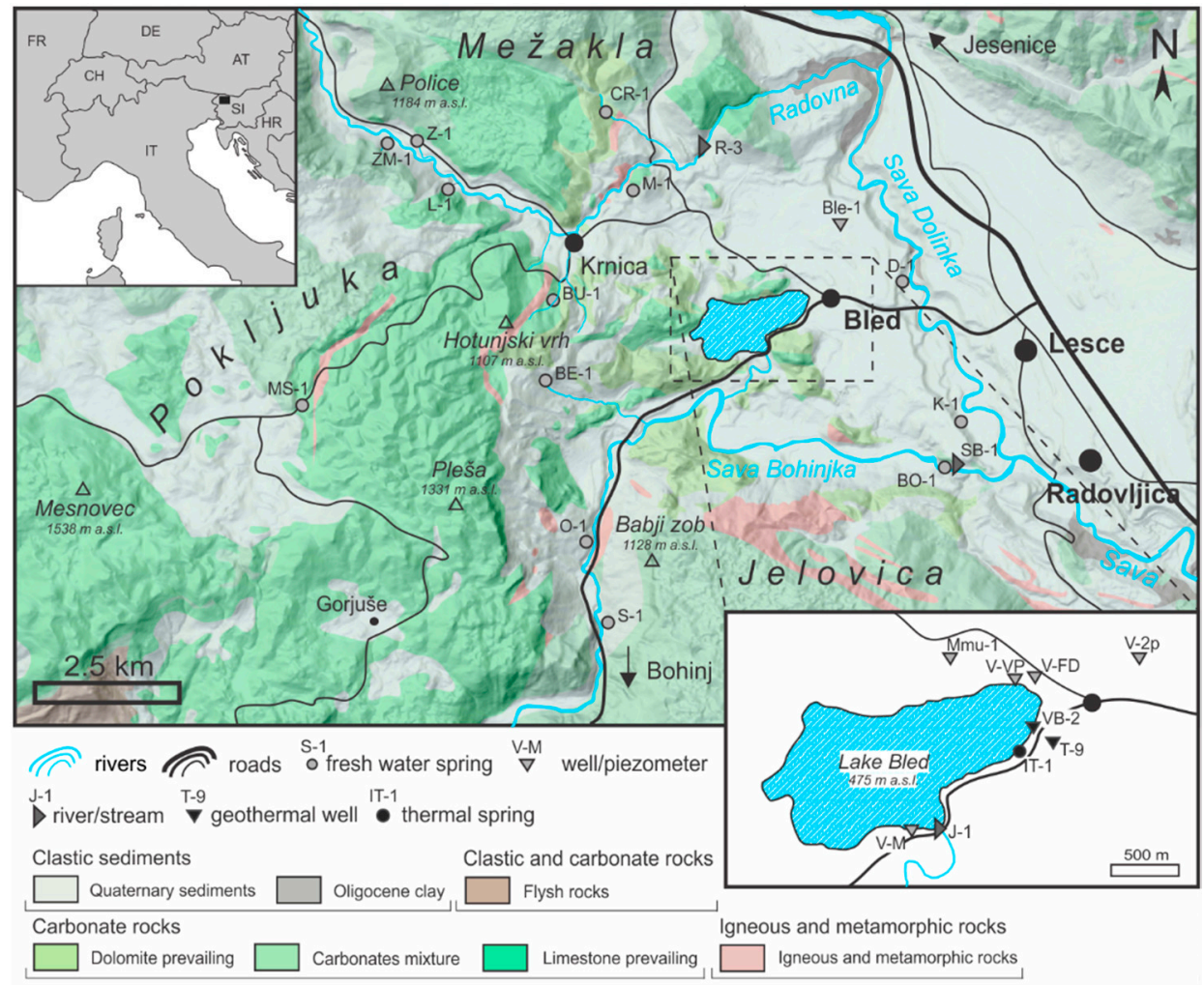

Figure 1. Observation area and sampling locations.

In Bled's meteorological station (longitude $=14.10^{\circ} \mathrm{E}$, latitude $=46.36^{\circ} \mathrm{N}, 482 \mathrm{~m}$ a.s.l.) only daily precipitation is measured. Other meteorological parameters (e.g., air temperature) are available at the meteorological station in Lesce (longitude $=14.17^{\circ} \mathrm{E}$, latitude $=46.37^{\circ} \mathrm{N}, 515 \mathrm{~m}$ a.s.l.). The average annual precipitation for standard 10-year (period of 2001-2010) in Bled is 1505 and in Lesce $1393 \mathrm{~mm}$ [37]. The annual average air temperature for this standard period in Lesce is $9.1^{\circ} \mathrm{C}$. 


\subsection{Geological Settings}

The investigated area is composed of carbonate and clastic rocks of Permian, Triassic, and Lower Jurassic ages, often covered by Oligocene-age sediment (marine clay) and Quaternary sediment (till, fluvio-glacial sediment, and slope sediment) deposits (Figure 1). The stratigraphy of the area was originally described by [38-40] and latter supplemented by [41,42]. The tectonic unit forming most of the highest mountains of the Julian Alps was in general defined as the Julian Nappe [43]. The oldest rocks considered are Permian Neoschwagerine limestones. Those rocks are outcropping only south from Bled Lake. Outcrops of mixed clastic and carbonate rocks of the Early Triassic (Werfen formation) are rare but are important horizons for understanding regional geological structure. At the beginning of the Middle Triassic, in the Anisian, only dolomites and limestones were formed. Anisian dolomites formed the surrounding hills of Bled lake. Ladinian rocks are positioned in the eastern part of Pokljuka and Mežakla, represented as light and brownish gray platy and stratified micritic limestone with cherts named the Zatrnik limestone [41]. These deeper water sediments were formed in the Bled Basin from the early Ladinian up to the Rhetium stage. At the same time, a complex trench-platform sedimentary environment resulted in a shallow slope and shelf water sediment environment; dolomites, dolomite breccia, rocks of Buchenstein formation, and upper Triassic bedded limestone and dolomite.

In the Late Triassic, the tectonic activities were accompanied by volcanism resulting in magmatic rocks which present the footwall of Ladinian carbonates. Numerous patches of volcanic rock are present on the Pokljuka, Mežakla, and Jelovica plateaus; however, their frequency is higher in the east than in the west. In the Oligocene, thick layers of marine clay were deposited and can be found on the eastern and east-northern parts of the area in the valleys of Sava and Radovna rivers. The events in the Quaternary had a particularly strong impact on geomorphology. Valley glaciers extended along the Alpine valleys. The most important glaciers influencing the geomorphology of Bled were the Bohinj glacier and the Radovna glacier [44,45]. Some remains from the glacier (moraines) can be also found at the Pokljuka plateau. The glacial activity and postglacial fluvial processes resulted in deposition of up to few $10 \mathrm{~m}$ of Quaternary sediments. By Bled Lake, clayed sediments can be found which were deposited due to different extents of the lake, which was varying during glacial and interglacial periods.

\subsection{Hydrogeological and Thermal Settings}

Thermal water with $20-23^{\circ} \mathrm{C}$ is exploited by two wells and the spring. Bled's geothermal system is classified as a low-temperature warm spring system [5]. In the past, before the modern pumping infrastructure was established, there were several thermal springs, but today only a spring named Toplice exists, with an average discharge of $5.5 \mathrm{~L} / \mathrm{s}$. Water discharges from fractures in the Triassic dolomite, covered by moraine and lake sediments. The dolomite represents the primary geothermal aquifer with fissured porosity, which is also exploited by well T-9/68 (screens on the interval 547-568 m). Based on the temperature log in well T-9/68, the geothermal gradient was estimated on $1{ }^{\circ} \mathrm{C} / 100 \mathrm{~m}[46]$, which means that thermal water is ascending from depths greater than $1000 \mathrm{~m}$. Moreover, it is assumed that the water is outflowing to the surface, either because of the presence of a fault zone or at the lithological contact between dolomite and Oligocene marine clay. N and NE from the Toplice spring, the thermal water is discharging from dolomite into the "secondary" geothermal aquifer represented by sandy-gravely sediments of Quaternary age. The secondary thermal aquifer is exploited by well VB-2/04 (exploitation depth $=47-71 \mathrm{~m}$ ). The fresh groundwater flow in the shallow aquifer is generally in the E-W direction. In addition, Lake Bled also represents the hydraulic boundary for groundwater flow, however the nature of the connection between Lake Bled and shallow groundwater is still unknown. 


\section{Methods}

\subsection{Data Acquisition}

Active water circulation in the area can be divided into four specific systems represented by (1) surface waters, (2) a Quaternary intergranular aquifer, (3) a Mesozoic shallow karstic-fissured aquifer, and (4) a deeper Mesozoic geothermal aquifer with fissured porosity (Figure 2). Each of them is defined with specific hydrogeological conditions, e.g., infiltration rate, hydraulic conductivity, characteristic water temperature, and electrical conductivity. In order to identify the relationship between thermal water and potential recharge areas, hydrogeochemical data of shallow fresh groundwater were obtained at 17 springs and wells (Table 1). Each spring/well was classified according to prevailing lithology in the recharge area (e.g., dolomite, limestone, Quaternary sediments). In addition, to satisfy the boundary conditions, hydrogeochemical data from rivers Sava Bohinjka (SB-1), Radovna (R-3), and Jezernica (J-1) were also taken into account.

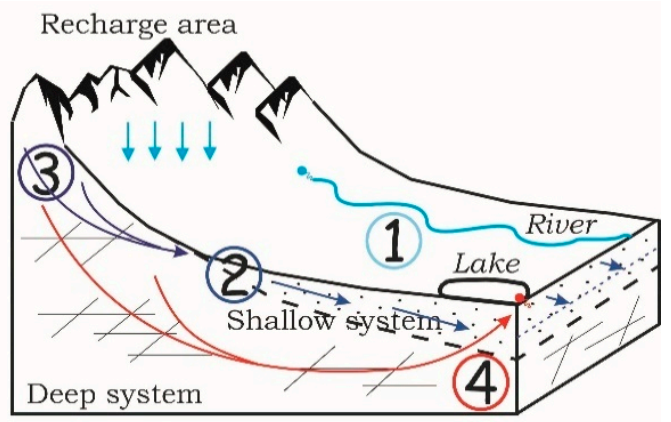

Figure 2. Conceptual approximation of hydrogeological systems in Bled area: (1) surface waters, (2) intergranular aquifer, (3) shallow karstic-fissured aquifer, and (4) deep geothermal aquifer.

The hydrogeochemical analyses included field parameters like groundwater temperature $(\mathrm{T})$, $\mathrm{pH}$, electrical conductivity (EC), major ions $\left(\mathrm{Na}^{+}, \mathrm{K}^{+}, \mathrm{Ca}^{2+}, \mathrm{NO}_{3}{ }^{-}, \mathrm{Mg}^{2+}, \mathrm{HCO}_{3}{ }^{-}, \mathrm{SO}_{4}{ }^{2-}\right.$ and $\left.\mathrm{Cl}^{-}\right)$, and some microelements $\left(\mathrm{Sr}^{2+}, \mathrm{B}^{3+}, \mathrm{Ba}^{2+}\right)$. Moreover, tritium activity and stable isotopes of oxygen and hydrogen in water $\left(\delta^{18} \mathrm{O}\right.$ and $\left.\delta^{2} \mathrm{H}\right)$ were taken into account.

Annually, the hydrogeochemical data of thermal water are obtained at three locations: One thermal spring (Toplice) and two wells (VB-2/04 and T-9/68) which hold a water concession. These waters are sampled and analyzed by the accredited Slovenian National Laboratory of Health, Environment and Food in accordance with their methods. Sampling of waters for isotope analyses was performed by Geological Survey of Slovenia. No water treatment was performed, samples for stable isotopes were stored in $50 \mathrm{~mL}$ HDPE (high density polyethylene) bottles and for tritium in $1 \mathrm{~L}$ bottles. These samples were analyzed at the Jožef Stefan Institute (JSI) in Ljubljana, Slovenia. Analyses were performed using Mass spectrometer Isoprime (CV Instruments). Analytical errors of the method were $\pm 0.10 \%$ o for $\delta^{18} \mathrm{O}$ and $\pm 1.0 \%$ o for $\delta^{2} \mathrm{H}$, respectively. Groundwater samples for radioactive isotope tritium $\left({ }^{3} \mathrm{H}\right)$ were analyzed by Hydrosys laboratory from Budapest using the electrolytic enrichment method. Tritium concentrations were expressed as tritium units (TU), where 1 TU equals to the activity of $0.118 \mathrm{~Bq} / \mathrm{kg}$ of water [47]. Besides these analyses, we used archive data from several wells: Object D-1 (only $\delta^{18} \mathrm{O}$ and $\delta^{2} \mathrm{H}$ ) [32]; objects ZM-1, Z-1, M-1, CR-1, and R-3 [35]; objects Ble-1, D-1 (only chemical analysis), $\mathrm{J}-1$, and BO-1 [48].

The majority of new water samples were gathered in 2018 and 2019. The latest chemical and isotope sampling campaign was carried out in January 2019 during low to medium hydrological conditions. Ten water samples were collected for major ions, microelements, stable isotopes, and tritium. Water samples collected for major ions and microelements were sampled and analyzed by the accredited Slovenian National Laboratory of Health, Environment and Food in accordance with their methods. The stable isotopes $\delta^{18} \mathrm{O}$ and $\delta^{2} \mathrm{H}$ were sampled and analyzed by Geological Survey of Slovenia. 
No water treatment was performed, samples for stable isotopes were stored in $50 \mathrm{~mL}$ HDPE bottles and analyzed using Picarro L2130-I instrument with a method Laser Cavity Ring-Down Spectroscopy (CRDS). In addition, three thermal water samples (in all three objects, T-9, VB-2, and T-9) were analyzed at the Jožef Stefan Institute (JSI). Methodology was the same as for regular annual monitoring. The same can be stated for tritium $\left({ }^{3} \mathrm{H}\right)$ analyses.

Table 1. Sampled objects and their characteristics.

\begin{tabular}{|c|c|c|c|c|c|c|c|c|}
\hline \multirow{2}{*}{ Object ID } & \multirow{2}{*}{ Object } & \multirow{2}{*}{ Type } & \multirow{2}{*}{ Hydrogeol. System } & \multirow{2}{*}{ Prevailing Lithology } & \multicolumn{2}{|c|}{ Chemical Analysis } & \multicolumn{2}{|c|}{ Isotopic Analysis } \\
\hline & & & & & Major & Micro & $\delta^{18} \mathrm{O}, \delta^{2} \mathrm{H}$ & ${ }^{3} \mathrm{H}$ \\
\hline SB-1 & $\begin{array}{c}\text { Sava } \\
\text { Bohinjka }\end{array}$ & River & SW & & 18 * & & & \\
\hline $\mathrm{R}-3$ & Radovna & River & SW & & $9 *$ & & & \\
\hline $\mathrm{J}-1$ & Jezernica & Stream & SW & & $4 *$ & & 3 & \\
\hline Ble-1 & Ble-1/13 & Piezometer & SI & Quaternary sediments & $2 *$ & & & \\
\hline D-1 & Dobravca & Spring & SI & Quaternary sediments & $13 *$ & & $1 *$ & \\
\hline $\mathrm{V}-\mathrm{VP}$ & V-VP & Piezometer & SI & Quaternary sediments & 1 & 1 & 3 & 1 \\
\hline V-M & V-M & Piezometer & SI & Quaternary sediments & 1 & 1 & 3 & 1 \\
\hline V-FD & V-FD & Piezometer & SI & Quaternary sediments & 1 & 1 & 3 & 1 \\
\hline$V-2 p$ & $V-2 p$ & Piezometer & SI & Quaternary sediments & 1 & 1 & 3 & 1 \\
\hline $\mathrm{K}-1$ & Koritno & Spring & SI & Quaternary sediments & 1 & 1 & 3 & 1 \\
\hline Mmu-1 & $\mathrm{Mmu}-1 / 18$ & Well & SKF & Dolomite & 1 & 1 & 4 & 1 \\
\hline CR-1 & Rečica & Spring & SKF & Dolomite & $3 *$ & & 2 & \\
\hline BO-1 & Bodešče & Spring & SKF & Dolomite & 1 & 1 & 4 & 1 \\
\hline Z-1 & Zatrep & Spring & SKF & Limestone & $3 *$ & & 1 & \\
\hline ZM-1 & Zrmzlek & Spring & SKF & Limestone & $4 *$ & & 2 & \\
\hline L-1 & Lipnik & Spring & SKF & Limestone & $7 *$ & & 2 & \\
\hline O-1 & Obrne & Spring & SKF & Limestone & 1 & 1 & 4 & 1 \\
\hline S-1 & Soteska & Spring & SKF & Limestone & 1 & 1 & 4 & 1 \\
\hline BU-1 & Budin & Spring & SKF & Limestone & 1 & 1 & 2 & 1 \\
\hline BE-1 & Belica & Spring & SKF & Limestone & 1 & 1 & 4 & 1 \\
\hline M-1 & Mevkuž & Spring & SKF & Limestone & & & 2 & \\
\hline MS-1 & $\begin{array}{c}\text { Mrzli } \\
\text { Studenec }\end{array}$ & Spring & SKF & Limestone & & & 3 & \\
\hline T-9 & $\mathrm{T}-9 / 68$ & Well & GA & Dolomite & 3 & 1 & 6 & 1 \\
\hline VB-2 & VB-2/04 & Well & GA & Quaternary sediments & 4 & 1 & 6 & 1 \\
\hline TS-1 & Toplice & Spring & GA & Dolomite & 3 & 1 & 6 & 1 \\
\hline
\end{tabular}

$\mathrm{SW}=$ surface water, $\mathrm{SI}=$ shallow intergranular aquifer, $\mathrm{SKF}=$ shallow karstic-fissured aquifer, GA = geothermal aquifer. ${ }^{*}$ Archive data.

\subsection{Data Processing}

In order to replace the unknown values below the limit of detection (LOD), we applied the LOD/2 method [49]. In order to exclude low-quality results, samples with ion balances (E.B.) exceeding approx. $\pm 10 \%$ were excluded from further analysis. The ion balance was calculated from the following equation:

$$
\text { E.B.: }(\%)=\left(\sum \text { cations }-\sum \text { anions }\right) /\left(\sum \text { cations }+\sum \text { anions }\right) \times 100 \%,
$$

where cations and anions are expressed as meq/L. For objects with more than one water sample available, a median value was calculated. In the case of trace elements and tritium, only one sampling campaign was available.

Graphical analysis of the classification of groundwater types was performed in AquaChem ${ }^{\circledR} 5.1$ (Waterloo Hydrogeologic Inc., Waterloo, ON, Canada), where the ion pattern was defined according to the concentration of the dominant dissolved species measured in groundwater. A trilinear Piper diagram [50], where all major ions are used for the classification, was applied to determine the hydrochemical facies. Additionally, a Gibbs [51] diagram was applied to separate the effects of natural processes such as precipitation, evaporation, and water-rock interaction. The Gibbs diagram expresses ratios of $\mathrm{Na}^{+} /\left(\mathrm{Na}^{+}+\mathrm{Ca}^{2+}\right)$ or $\mathrm{Cl}^{-} /\left(\mathrm{Cl}^{-}+\mathrm{HCO}_{3}{ }^{-}\right)$in order to source ions from a variety of natural processes. However, it was recognized that the Gibbs diagram may oversimplify the interpretation of aquifer systems and overlook important processes [52]. Therefore, it is necessary to consider other sophisticated diagrams (e.g., Piper plot). Moreover, the molar ratio between $\mathrm{Ca}^{2+}$ and $\mathrm{Mg}^{2+}$ in groundwater was used to indicate the relative proportion of rocks in the recharge area. In literature, however, it is assumed that values equal to 1 indicate dissolution of dolomite and dolomite prevailing 
in the recharge area [53]. Higher $\mathrm{Ca}^{2+} / \mathrm{Mg}^{2+}$ molar ration $(>2)$ is a result of prevailing calcite rocks. The saturation indices (SI) of dolomite and calcite were calculated to evaluate chemical equilibrium using AquaChem ${ }^{\circledR}$ 5.1, based on the following equation:

$$
\mathrm{SI}=\log \left(I A P / K_{T}\right)
$$

where IAP is ion activity product and $K_{T}$ the equilibrium constant at specific temperature. Positive SI values $(S I>0)$ show mineral oversaturation and precipitation, while negative SI values $(S I<0)$ imply unsaturated solutions and mineral dissolution. The assumed tolerant equilibrium range with respect to mineral is \pm 0.1 SI for calcite \pm 0.5 SI for dolomite [54].

The studied dataset was summarized with several descriptive statistics: Mean (Av), minimum (Min), maximum (Max), and range (R). Major ions, $\mathrm{pH}$, and TDS were used for principal component analysis (PCA) to identify the relationship between the variables and evaluate factors affecting hydrochemical components [55]. In order to ensure that the variables make an equal contribution to the computed value, standardization based on distribution characterized by mean and standard deviation was used. Most of the analyses in the study were performed using the dplyr package [56] included in $\mathrm{R}$, a software environment for statistical computing and graphics [57].

Groundwater stable isotope compositions $\left(\delta^{18} \mathrm{O}\right.$ and $\left.\delta^{2} \mathrm{H}\right)$ were used to provide information about the recharge area characteristics. The $\delta^{18} \mathrm{O}$ and $\delta^{2} \mathrm{H}$ isotopic composition of meteoric waters were strongly correlated [58]. Fresh groundwater and thermal water values of $\delta^{18} \mathrm{O}$ and $\delta^{2} \mathrm{H}$ were compared to a global meteoric water line (GMWL) defined as $\delta^{2} \mathrm{H}=8.13 \delta^{18} \mathrm{O}+10.8$ (\%o) [59], to which the local meteoric water line for Ljubljana GNIP precipitation was very close [60], the Eastern Mediterranean meteoric water line (EMMWL) was $\delta^{2} \mathrm{H}=8 \delta^{18} \mathrm{O}+22$ [61], and the updated Northern Italy meteoric water line (LMWL North Italy) was $\delta^{2} \mathrm{H}=8.04 \delta^{18} \mathrm{O}+11.47$ [62]. Recharge altitude was calculated based on a simple linear model:

$$
h_{\mathrm{avg}}=\left(\delta^{18} \mathrm{O}_{\mathrm{avg}} \times a\right)+b
$$

where $h_{\text {ave }}$ is the calculated average recharge altitude for the selected location, $\delta^{18} \mathrm{O}_{\text {ave }}$ is the mean $\delta^{18} \mathrm{O}$ value for the selected location, and $a$ and $b$ are the slope and intercept, respectively, defined by the springs with small recharge area.

Tritium data can provide an estimation of groundwater age, or time since groundwater was recharged [25]. The year 1953 is used as a threshold for distinguishing young from old groundwaters, since widespread nuclear weapons testing was performed in the atmosphere between 1953 and 1963 [63]. Tritium content in precipitation was $\sim 5$ to $\sim 500$ times higher than that of natural pre-bomb levels. But tritium data alone cannot provide the age of groundwater since it requires long time series data at particular sampling location. The tritium activity has been continually decreasing since 1963, which is also the case in the two closest locations the interpretation of groundwater tritium content has to consider the closest precipitation measurement locations (Figure 3).

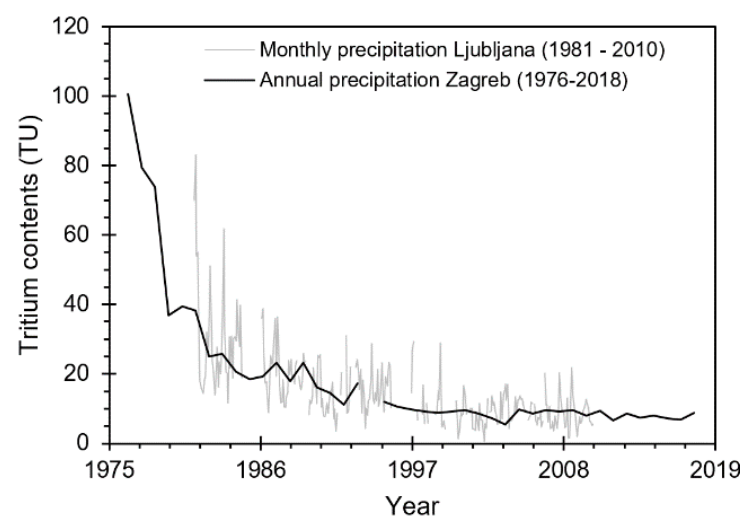

Figure 3. Tritium content data from two measurements locations, Ljubljana [60,64] and Zagreb [58]. 


\section{Results}

\subsection{Major Ion Chemistry}

There are four distinctive types of water: (1) Surface waters $\left(\mathrm{T}_{\mathrm{avg}}=10.3^{\circ} \mathrm{C}, \mathrm{EC}_{\mathrm{avg}}=282 \mu \mathrm{S} / \mathrm{cm}\right)$; (2) shallow groundwater in limestone and dolomite rocks $\left(\mathrm{T}_{\mathrm{avg}}=7.3^{\circ} \mathrm{C}, \mathrm{EC}_{\mathrm{avg}}=296 \mu \mathrm{S} / \mathrm{cm}\right)$; (3) fresh shallow groundwater in glaciofluvial sediments $\left(\mathrm{T}_{\mathrm{avg}}=10.2^{\circ} \mathrm{C}, \mathrm{EC}_{\mathrm{avg}}=472 \mu \mathrm{S} / \mathrm{cm}\right)$; and (4) thermal water $\left(\mathrm{T}_{\mathrm{avg}}=20.8^{\circ} \mathrm{C}, \mathrm{EC}_{\mathrm{avg}}=785 \mu \mathrm{S} / \mathrm{cm}\right)$.

Chemical parameter ranges are shown in Figure 4. The values of $\mathrm{pH}$ show a range between 6.9 and 8.5 (Tables 2 and 3) which are within the expected range of groundwater natural background values [32]. The groundwater in the Quaternary aquifer had low concentrations of major ions $\left(\mathrm{Ca}^{2+}\right.$, $\mathrm{Mg}^{2+}$ in $\left.\mathrm{HCO}_{3}{ }^{-}\right)$. The high electrical conductivity $(383 \mu \mathrm{S} / \mathrm{cm}-566 \mu \mathrm{S} / \mathrm{cm})$ was due to a quite high mineralization and a high concentration of $\mathrm{HCO}_{3}{ }^{-}(348.6 \mathrm{mg} / \mathrm{L}-521.0 \mathrm{mg} / \mathrm{L})$. Nitrate concentrations in groundwater are low, up to $13 \mathrm{mg} / \mathrm{L}$. In some cases, values were below the LOD of $2.2 \mathrm{mg} / \mathrm{L}$. Although the average $\mathrm{NO}_{3}{ }^{-}$concentrations were in the range of natural background level, some higher concentrations can be attributed to land use.

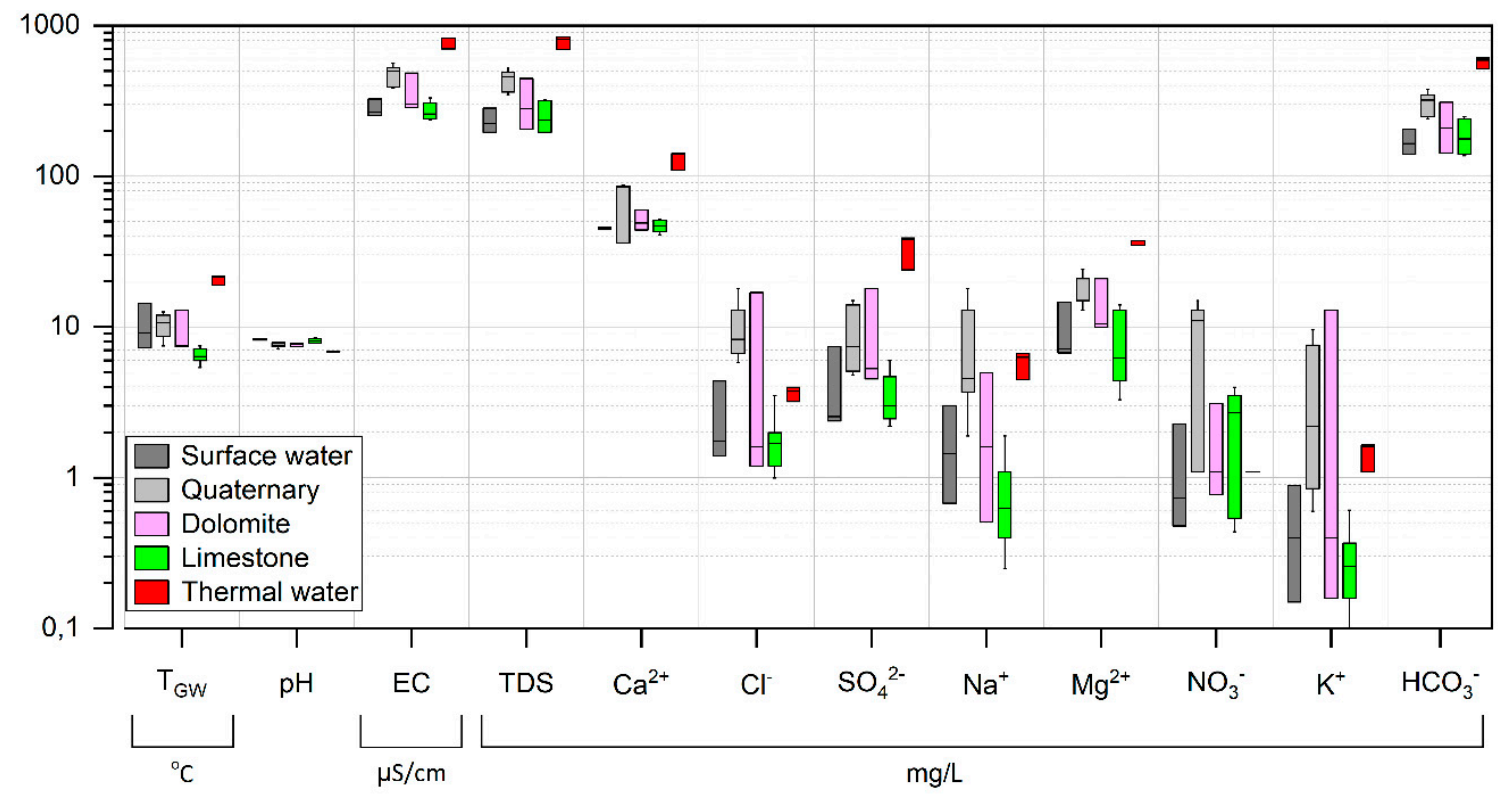

Figure 4. Box plots of major ions in different hydrogeological systems.

Karstic springs have relatively low mineralization $(194.4 \mathrm{mg} / \mathrm{L}-323.0 \mathrm{mg} / \mathrm{L})$, which is related to a high mountain recharge area with a mountain climate. The only exemption is well $\mathrm{Mmu}-1$, which had higher concentrations of $\mathrm{K}^{+}, \mathrm{Na}^{+}, \mathrm{Cl}^{-}, \mathrm{SO}_{4}{ }^{2-}$ and consequently higher TDS (445.1 mg/L). Mineralization in thermal water was significantly higher than in groundwater wells and springs and varied between 698.9-841.2 mg/L. Additionally, the concentrations of $\mathrm{Mg}^{2+}, \mathrm{Ca}^{2+}$, and $\mathrm{SO}_{4}{ }^{2-}$ were higher compared to those of fresh groundwaters and surface waters. Nitrate is LOD ( $<2.2 \mathrm{mg} / \mathrm{L})$, which indicated that the geothermal aquifer was well protected from surface contamination sources.

The Piper diagram and resulting water types are shown in Figure 5. All investigated water samples were classified as $\mathrm{Ca}^{2+}-\mathrm{HCO}_{3}{ }^{-}$and $\mathrm{Ca}^{2+}-\mathrm{Mg}^{2+}-\mathrm{HCO}_{3}{ }^{-}$types. Only the Sava Bohinjka river and five freshwater springs indicated a $\mathrm{Ca}^{2+}-\mathrm{HCO}_{3}{ }^{-}$type. The majority of freshwater samples, including groundwater in shallow aquifers and surface waters, were classified as $\mathrm{Ca}^{2+}-\mathrm{Mg}^{2+}-\mathrm{HCO}_{3}{ }^{-}$. The same water type was determined for thermal water samples. 
Table 2. Results for all water samples including major ion chemistry, trace elements, and stable isotopes.

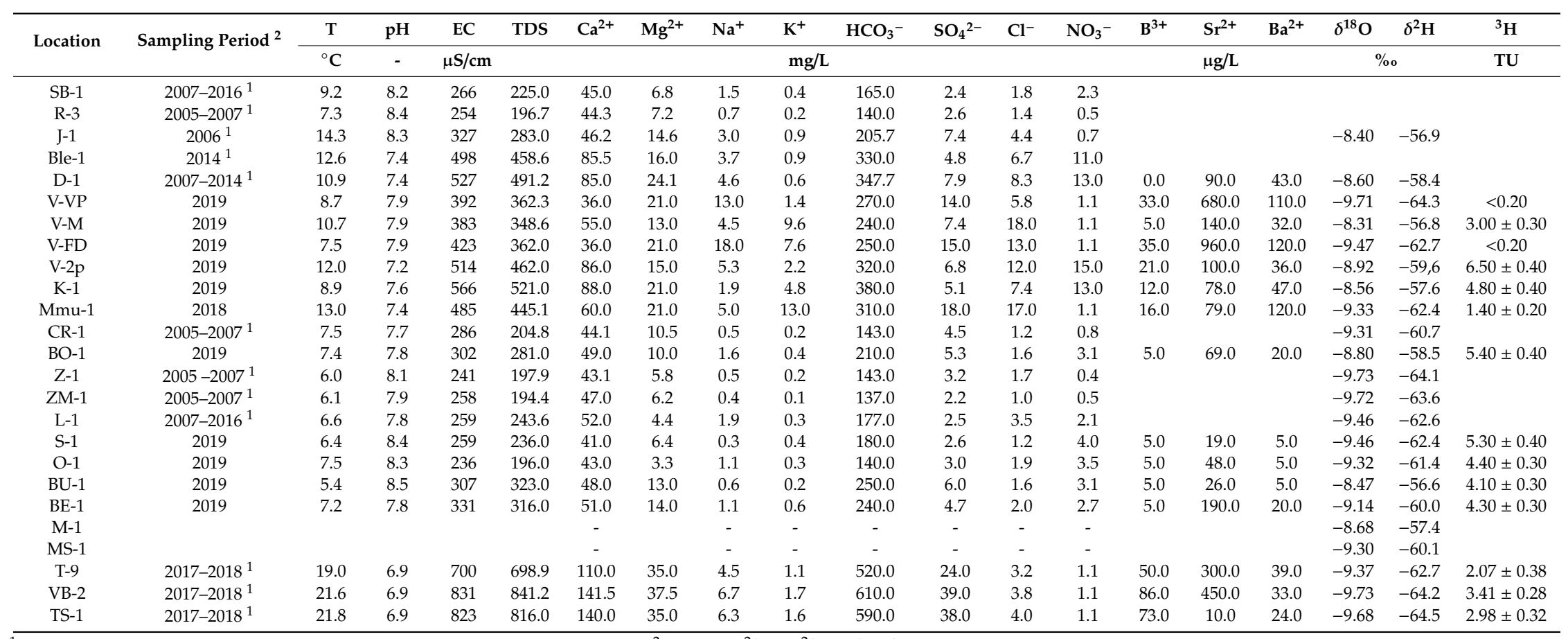

${ }^{1}$ More than one sample was available in the case of major ions $\left(\mathrm{NO}_{3}{ }^{-}, \mathrm{SO}_{4}{ }^{2-}, \mathrm{Cl}^{-}, \mathrm{Ca}^{2+}, \mathrm{Mg}^{2+}, \mathrm{Na}^{+}, \mathrm{K}^{+}\right.$, and $\left.\mathrm{HCO}_{3}{ }^{-}\right)$and therefore the calculated value represents the median value. 2 Sampling period is presented for chemical parameters. 
Table 3. Descriptive statistics by hydrogeological systems and prevailing lithology.

\begin{tabular}{|c|c|c|c|c|c|c|c|c|c|c|c|c|c|c|c|}
\hline \multirow{2}{*}{$\begin{array}{c}\text { Hydrogeol. } \\
\text { System }\end{array}$} & \multirow{2}{*}{$\begin{array}{c}\text { Prevailing } \\
\text { Lithology }\end{array}$} & \multirow{2}{*}{ Statistics } & \multirow{2}{*}{$\mathbf{N}$} & \multirow{2}{*}{$\begin{array}{c}\mathrm{T} \\
{ }^{\circ} \mathrm{C} \\
\end{array}$} & \multirow{2}{*}{$\frac{\mathrm{pH}}{/}$} & \multirow{2}{*}{$\begin{array}{c}\text { EC } \\
\mu \mathrm{S} / \mathrm{cm}\end{array}$} & TDS & $\mathrm{Ca}^{2+}$ & $\mathrm{Mg}^{2+}$ & $\mathrm{Na}^{+}$ & $\mathrm{K}^{+}$ & $\mathrm{HCO}_{3}^{-}$ & $\mathrm{SO}_{4}{ }^{2-}$ & $\mathrm{Cl}^{-}$ & $\mathrm{NO}_{3}{ }^{2-}$ \\
\hline & & & & & & & \multicolumn{9}{|c|}{$\mathrm{mg} / \mathrm{L}$} \\
\hline \multirow{4}{*}{ SW } & \multirow{4}{*}{ - } & Min & \multirow{4}{*}{3} & 7.3 & 8.2 & 254 & 196.7 & 44.3 & 6.8 & 0.7 & 0.2 & 140 & 2.4 & 1.4 & 0.5 \\
\hline & & $\operatorname{Max}$ & & 14.3 & 8.4 & 327 & 283 & 46.2 & 14.6 & 3 & 0.9 & 205.7 & 7.4 & 4.4 & 2.3 \\
\hline & & $\mathrm{Av}$ & & 10.3 & 8.3 & 282 & 234.9 & 45.2 & 9.5 & 1.7 & 0.5 & 170.2 & 4.1 & 2.5 & 1.2 \\
\hline & & St. dev. & & 3.6 & 0.1 & 38.9 & 44 & 1 & 4.4 & 1.2 & 0.4 & 33.2 & 2.9 & 1.6 & 1 \\
\hline \multirow{4}{*}{ SI } & \multirow{4}{*}{$\begin{array}{l}\text { Quaternary } \\
\text { sediments }\end{array}$} & Min & \multirow{4}{*}{7} & 7.5 & 7.2 & 383 & 348.6 & 36 & 13 & 1.9 & 0.6 & 240 & 4.8 & 5.8 & 1.1 \\
\hline & & Max & & 12.6 & 7.9 & 566 & 521 & 88 & 24.1 & 18 & 9.6 & 380 & 15 & 18 & 15 \\
\hline & & $\mathrm{Av}$ & & 10.2 & 7.6 & 472 & 429.4 & 67.4 & 18.7 & 7.3 & 3.9 & 305.4 & 8.7 & 10.2 & 7.9 \\
\hline & & St. dev. & & 1.9 & 0.3 & 71.9 & 70.3 & 24.3 & 4.1 & 5.9 & 3.6 & 52.9 & 4.1 & 4.4 & 6.5 \\
\hline \multirow{8}{*}{ SKF } & \multirow{5}{*}{ Limestone } & Min & \multirow{4}{*}{7} & 5.4 & 7.8 & 236 & 194.4 & 41 & 3.3 & 0.3 & 0.1 & 137 & 2.2 & 1 & 0.4 \\
\hline & & Max & & 7.5 & 8.5 & 331 & 323 & 52 & 14 & 1.9 & 0.6 & 250 & 6 & 3.5 & 4 \\
\hline & & Av & & 6.5 & 8.1 & 270 & 243.8 & 46.4 & 7.6 & 0.8 & 0.3 & 181 & 3.5 & 1.8 & 2.3 \\
\hline & & St. dev. & & 3.2 & 0.2 & 110.6 & 122.8 & 8.1 & 6.2 & 2.3 & 7.3 & 84 & 7.6 & 9 & 1.3 \\
\hline & & Min & \multirow{4}{*}{3} & 7.4 & 7.4 & 286 & 204.8 & 44.1 & 10 & 0.5 & 0.2 & 143 & 4.5 & 1.2 & 0.8 \\
\hline & \multirow{3}{*}{ Dolomite } & Max & & 13 & 7.8 & 485 & 445.1 & 60 & 21 & 5 & 13 & 310 & 18 & 17 & 3.1 \\
\hline & & $\mathrm{Av}$ & & 9.3 & 7.6 & 358 & 310.3 & 51 & 13.8 & 2.4 & 4.5 & 221 & 9.3 & 6.6 & 1.7 \\
\hline & & St. dev. & & 0.7 & 0.3 & 35.3 & 55.3 & 4.2 & 4.2 & 0.6 & 0.2 & 47.1 & 1.4 & 0.8 & 1.4 \\
\hline \multirow{4}{*}{ GA } & \multirow{4}{*}{ Dolomite } & Min & \multirow{4}{*}{3} & 19 & 6.9 & 700 & 698.9 & 110 & 35 & 4.5 & 1.1 & 520 & 24 & 3.2 & 1.1 \\
\hline & & Max & & 21.8 & 6.9 & 831 & 841.2 & 141.5 & 37.5 & 6.7 & 1.7 & 610 & 39 & 4 & 1.1 \\
\hline & & $\mathrm{Av}$ & & 20.8 & 6.9 & 785 & 785.4 & 130.5 & 35.8 & 5.8 & 1.5 & 573.3 & 33.7 & 3.7 & 1.1 \\
\hline & & St. dev. & & 1.6 & 0 & 733 & 75.9 & 17.8 & 1.4 & 1.2 & 0.3 & 47.3 & 8.4 & 0.4 & 0 \\
\hline
\end{tabular}

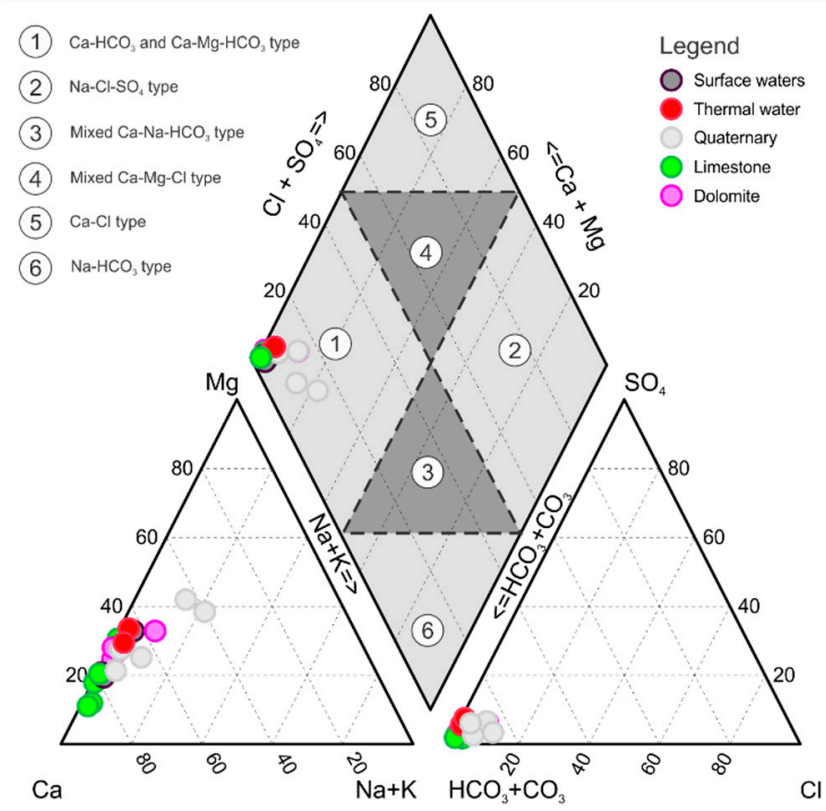

Figure 5. Piper diagram for 23 examined water samples.

The results of the principal component analysis include eigenvalues, percentage of variance, cumulative percentage of variance, and the factor loadings presented in Figure 6. An eigenvalue $>1$ indicated that the principle components (PCs) accounted for more variance than accounted by one of the original variables in standardized data. Using the Kaiser Criterion and scree plot, three PCs of eigenvalue greater than 1 were obtained, accounting for the total variance of $90.5 \%$. PC1 was responsible for $48 \%$ of total variance and had a strong positive loading of TDS, $\mathrm{Mg}^{2+}, \mathrm{Ca}^{2+}$, and $\mathrm{HCO}_{3}{ }^{-}$. This indicates that the major hydrochemical processes could be explained by the water-rock interaction predominant by the dissolution of dolomite $\left.(\mathrm{Ca}, \mathrm{Mg})\left(\mathrm{CO}_{3}\right)_{2}+2 \mathrm{H}_{2} \mathrm{CO}_{3} \rightarrow \mathrm{Ca}^{2+}+\mathrm{Mg}^{2+}+4 \mathrm{HCO}_{3}{ }^{-}\right)$. Higher values of $\mathrm{SO}_{4}{ }^{2-}$ were also typical for upper Triassic dolomites, resulting from dispersed gypsum dissolution [32] or oxidation of pyrite. Since water samples were also classified as $\mathrm{Ca}^{2+}-\mathrm{HCO}_{3}{ }^{-}$type, it was assumed that the dissolution of calcite $\left(\mathrm{CaCO}_{3}+\mathrm{H}_{2} \mathrm{CO}_{3} \rightarrow \mathrm{Ca}^{2+}+2 \mathrm{HCO}_{3}{ }^{-}\right)$was significant. 

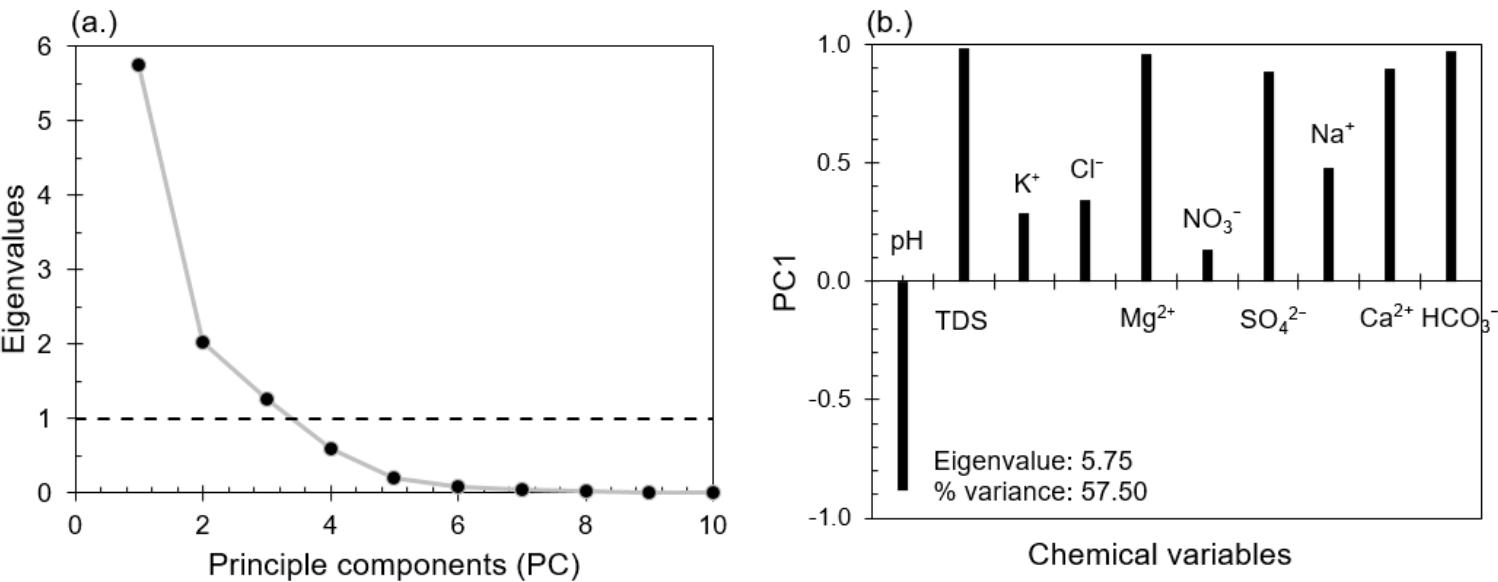

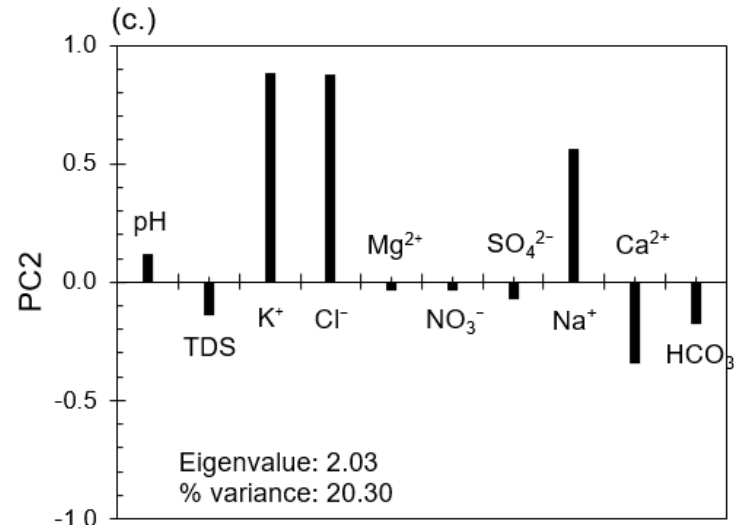

Chemical variables

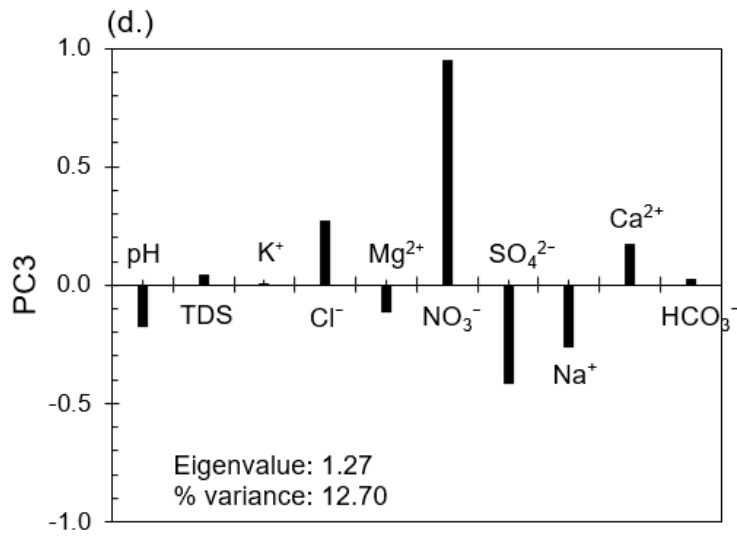

Chemical variables

Figure 6. Scree plot (a); factor loadings for (b), PC1, (c), PC2 and (d) PC3.

PC2 explained $20.3 \%$ of total variance and had a medium positive value of $\mathrm{K}^{+}, \mathrm{Cl}^{+}$, and $\mathrm{Na}^{+}$. PC3 contributed only $12.7 \%$ of total variance and only included a single major species $\mathrm{NO}_{3}{ }^{2+}$. As expected, the water-rock interaction represented by the dissolution of carbonate minerals (calcite and dolomite) was the main factor controlling dissolved hydrochemical components of water samples (Figure 7).
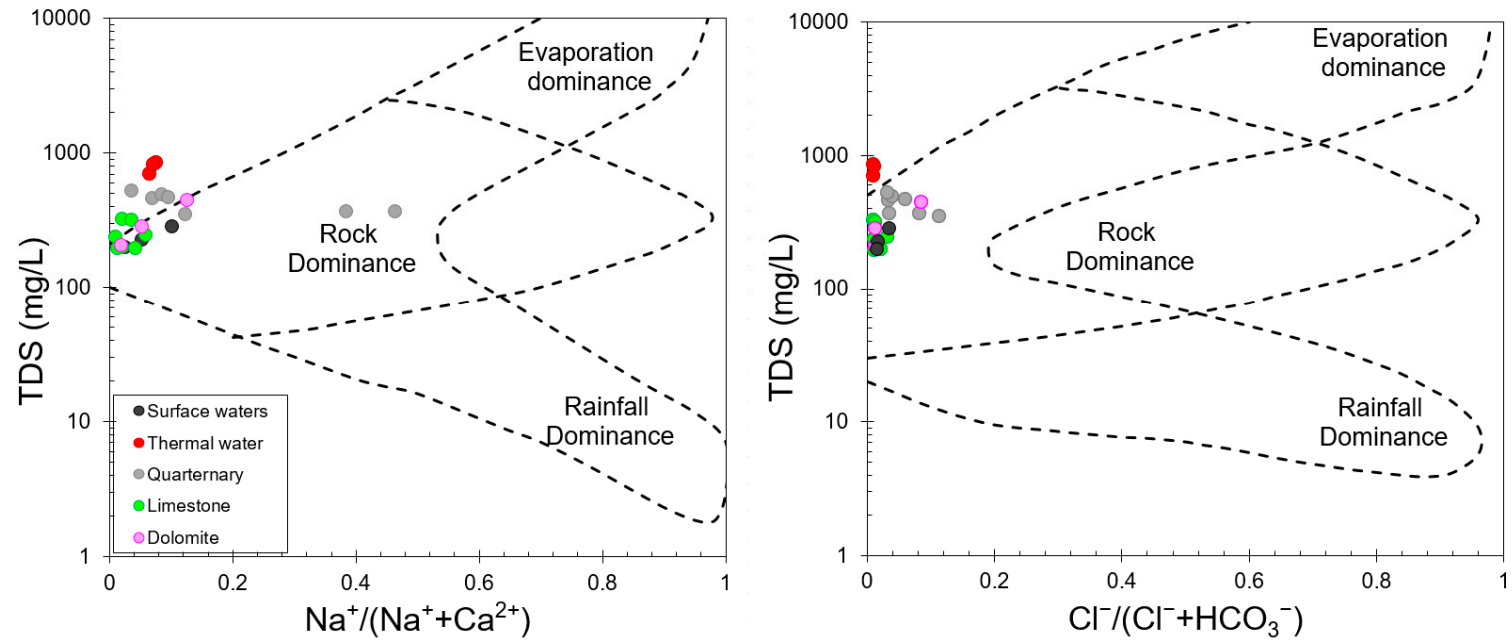

Figure 7. Gibbs diagrams for: (left figure) TDS vs. $\mathrm{Na}^{+} /\left(\mathrm{Na}^{+}+\mathrm{Ca}^{2+}\right)$ and (right figure) TDS versus $\mathrm{Cl}^{-} /\left(\mathrm{Cl}^{-}+\mathrm{HCO}_{3}^{-}\right)$. 
The three lines (Figure 8, left) illustrate the $\mathrm{Ca}^{2+} / \mathrm{Mg}^{2+}$ molar concentrations indicating the dissolution of calcite and dolomite, respectively. $\mathrm{A} \mathrm{Ca}^{2+} / \mathrm{Mg}^{2+}$ molar ratio $>1$ prevailed in all the sampled groundwater (Figure 8, right). Lower $\mathrm{Ca}^{2+} / \mathrm{Mg}^{2+}$ molar ratios $(<4)$ indicated a groundwater origin in dolomite and mixed dolomite with limestone. Groundwater with a higher molar ratio $(>4)$ indicated a limestone prevalence in the recharge area. The significant value of $\mathrm{Mg}^{2+}$ in thermal water indicated that the dolomite represented an important lithology in the recharge area. The correlation of the major ions (Figure 8) suggested that the recharge area of thermal water was represented by both limestone and dolomite rocks.
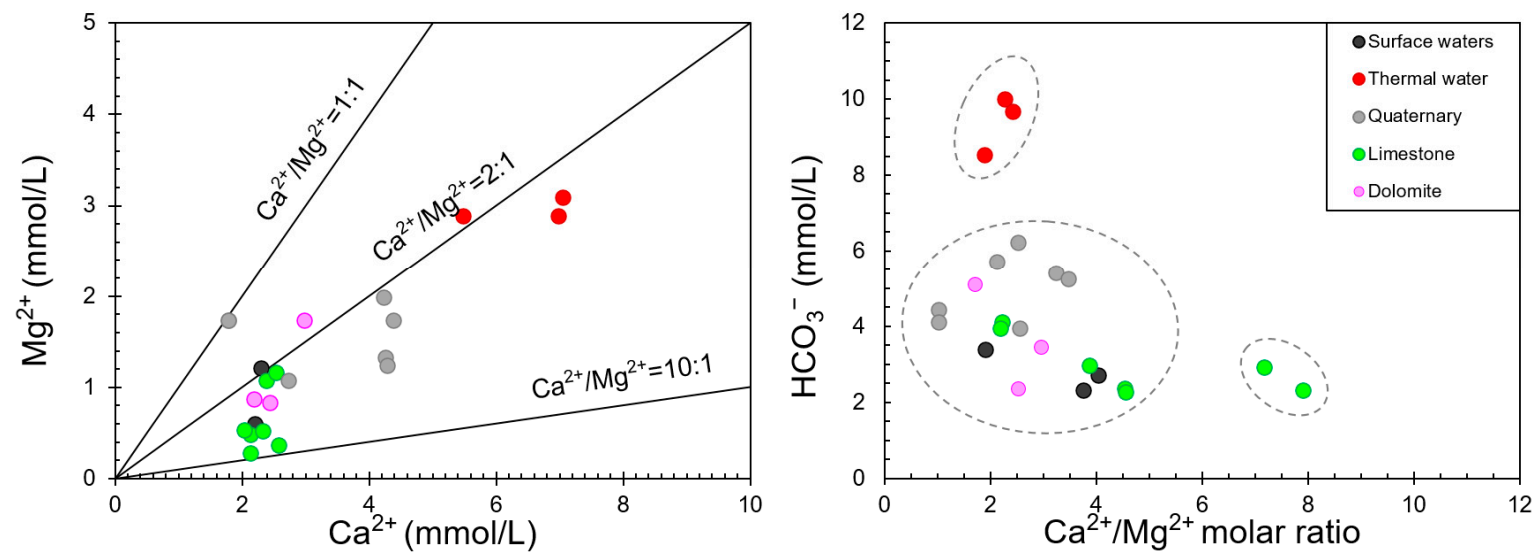

Figure 8. Relationship between $\mathrm{Mg}^{2+}$ and $\mathrm{Ca}^{2+}$ (left figure) and $\mathrm{HCO}_{3}{ }^{-}$and $\mathrm{Ca}^{2+} / \mathrm{Mg}^{2+}$ molar ratio (right figure).

\subsection{Saturation Indices}

If chemical equilibrium could be reached, the chemical composition of the geothermal fluid would give an important indication of host rock nature and its characteristics. Still, as this is a low-temperature geothermal system, the studies have shown that methods as geothermometers, for example, cannot be used directly [65].

The calcite and dolomite saturation index ranged from -0.19 to 0.83 and from -0.93 to 1.12 , respectively (Figure 9). The majority of water samples were oversaturated with calcite (tolerance was $\pm 0.1 \mathrm{SI}$ ) and in equilibrium with dolomite (tolerance is $\pm 0.5 \mathrm{SI}$ ). Only one sample was undersaturated with respect to calcite, possibly due to the low $\mathrm{HCO}_{3}{ }^{-}$concentration and low $\mathrm{EC}$, which was due to short retention time. Two samples were oversaturated and four samples undersaturated with respect to dolomite. Undersaturation with dolomite was probably because the water chemistry of those samples was controlled by calcite dissolution.

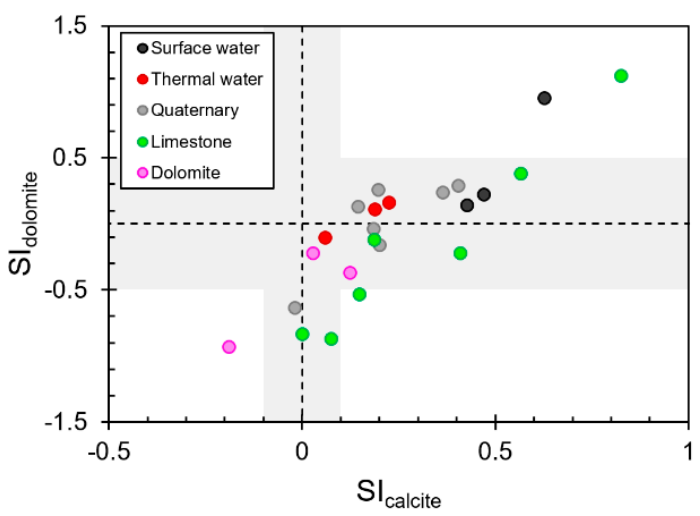

Figure 9. Saturation indices (SI) for calcite and dolomite. 


\subsection{Mixing of Groundwaters}

In this study, we used chemical tracers $\mathrm{Cl}^{-}, \mathrm{Sr}^{2+}, \mathrm{B}^{3+}$, and $\mathrm{Ba}^{2+}$ to delineate flow directions and evaluate possible mixing processes (Figure 10). Only groundwaters were taken into account since there were no data available for surface waters. A strong positive correlation was calculated between TDS and $\mathrm{B}^{3+}(\mathrm{R}=0.81)$. Boron occurs in most natural groundwater and surface waters in very small quantities, and each increment of concentration is over-proportional compared with the concentration rise for other water compounds already found in much higher concentrations under natural conditions [66]. This fact, together with the high mobility of boron compounds, makes boron a useful indicator and tracer when investigating hydrogeological problems. The lowest concentrations of TDS and $\mathrm{B}^{3+}$ could be observed for springs in the shallow karstic-fissured aquifer, while the highest concentrations were in thermal water. Hence, the groundwater flow in the shallow karstic-fissured aquifer had very short residence time, while in the deep fissured aquifer the residence time was much longer. The other three groups indicated no correlation, due to outliers: Piezometers V-VP and V-FD. They were located near the thermal spring $(\sim 500 \mathrm{~m})$ cone and therefore may have indicated mixing processes with fresh water; however, most likely the higher values were due to low groundwater velocity in confined glaciofluvial sediments (also with clay), where the oxygen content was very low. There was also well Mmu- 1 with a relatively higher content of barium and chloride. As the mineralization and typical anthropogenic ions $\left(\mathrm{SO}_{4}{ }^{2-}, \mathrm{K}^{+}, \mathrm{Na}^{+}\right)$were also high, they might indicate anthropogenic sources. The higher content of $\mathrm{Cl}^{-}$ in piezometer V-M was probably due to the proximity of the main road Bled-Bohinj, where a significant amount of road salt is used during winter. Therefore, we also calculated the correlations excluding the outliers. The strongest correlation was calculated for $\mathrm{Sr}^{2+}(\mathrm{R}=0.81)$. Hence, like in case before, the lowest concentrations of TDS and $\mathrm{Sr}^{2+}$ can be observed for springs in the shallow karstic-fissured aquifer, while the highest concentration of TDS and $\mathrm{Sr}^{2+}$ can be observed for the deep fissured aquifer (thermal water) due to larger retention time.
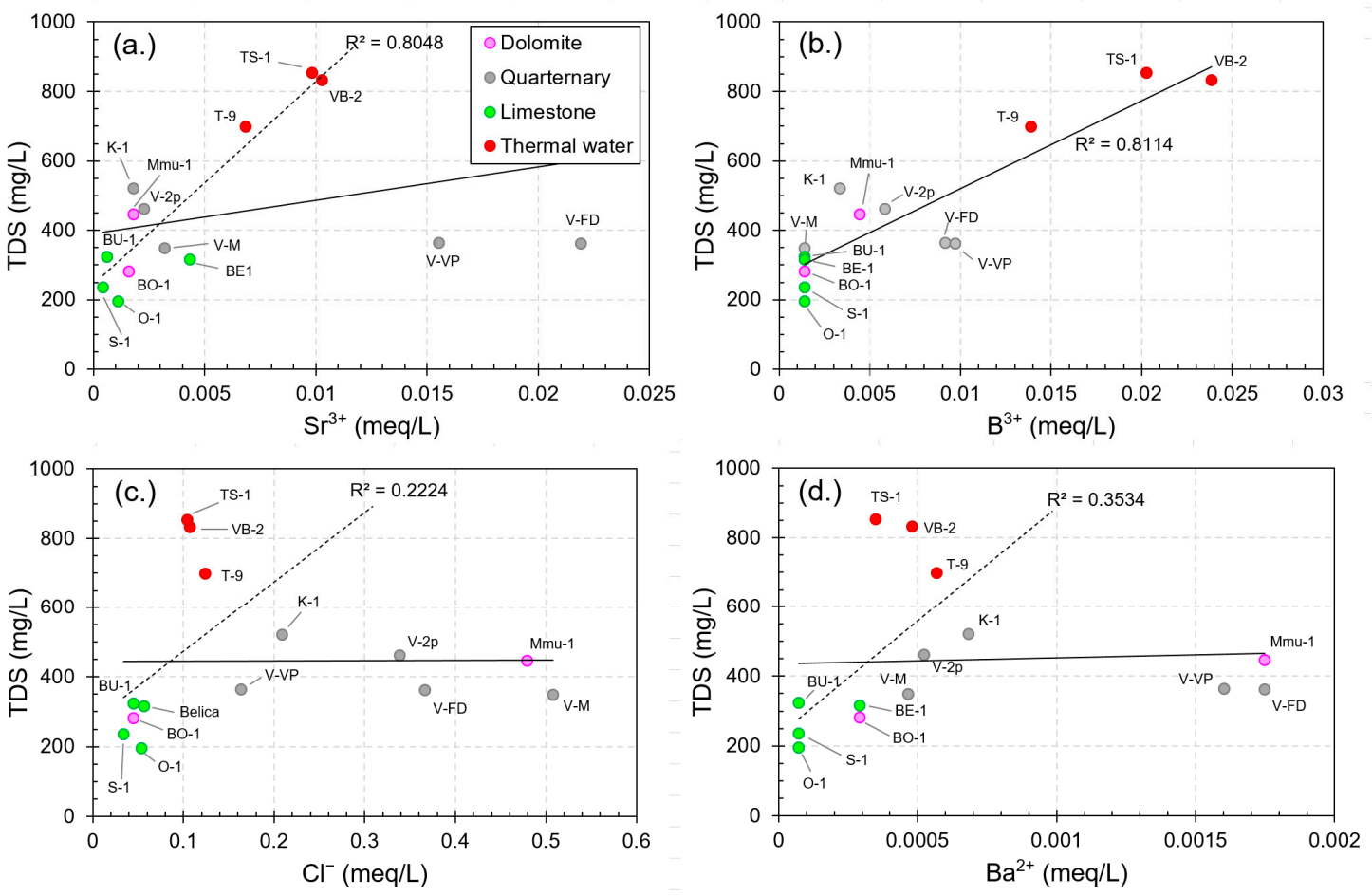

Figure 10. The relationship between total dissolved solids (TDS) and the conservative tracers, (a) $\mathrm{Sr}^{2+}$ (b) $\mathrm{B}^{3+}(\mathbf{c}) \mathrm{Cl}^{-}$and (d) $\mathrm{Ba}^{2+}$. 


\subsection{Origin of Waters and Recharge Altitudes}

The average $\delta^{18} \mathrm{O}$ and $\delta^{2} \mathrm{H}$ of the thermal water samples ranged from $-9.73 \%$ o to $-8.31 \%$ and from $-64.5 \%$ o to $-56.6 \%$, respectively (Figure 11 ). In the non-thermal groundwater samples, they ranged from $-9.72 \%$ o to $-8.31 \%$ and from $-64.3 \%$ o to $-56.6 \%$, respectively. Compared to Lake Bled, with an average value of $\delta^{18} \mathrm{O}$ as $-8.40 \%$ ond $-56.9 \%$ o for $\delta^{2} \mathrm{H}$, the geothermal water samples were relatively depleted. The results show that the majority of samples were between GMWL and EMMWL and were fitting well with LMWL for North Italy (Figure 11).

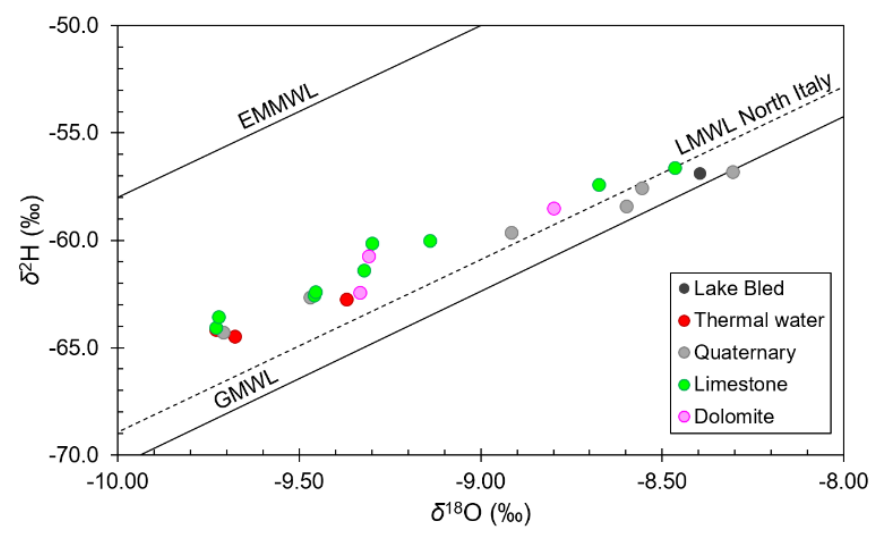

Figure 11. Stable isotopes of $\delta^{18} \mathrm{O}$ and $\delta^{2} \mathrm{H}$ in thermal water and groundwater.

In order to estimate the average recharge altitude for the investigated samples, two springs were taken into account: Mevkuž (M-1) and Mrzli Studenec (MS-1). For both springs, it was hypothesized that the isotopic signature of spring water was due to a small catchment area equal to the isotopic signature of precipitation at the corresponding altitude. M-1 was selected because it was already included in the previous investigations, while MS-1 is one of the highest springs in the observation area with a constant discharge and a relatively small recharge area. The altitude difference between springs M-1 (629) and MS-1 (1216 m a.s.1.) is $587 \mathrm{~m}$. The isotopic composition of those two springs suggests the range of $\delta^{18} \mathrm{O}=-8.68 \%$ o, $\delta^{2} \mathrm{H}=-57.4 \%$ at an elevation of $629 \mathrm{~m}$, and $\delta^{18} \mathrm{O}=-9.30 \%$, $\delta^{2} \mathrm{H}=$ $-60.1 \%$ o at an elevation of $1216 \mathrm{~m}$. Average recharge altitudes were estimated with stable isotope $\delta^{18} \mathrm{O}$ and determined using simple linear model as in Equation (3). Calculations with $\delta^{2} \mathrm{H}$ values were not adequate and deviated excessively from the $\delta^{18} \mathrm{O}$ altitude estimation. The slope and intercept of the linear model was determined with $a(-939.2)$ and $b(-7518.6)$, respectively, defined by the $\delta^{18} \mathrm{O}$ mean values and altitude difference of the springs M-1 and MS-1. The estimated average altitude effect for the observation area was $-0.11 \%$ o per $100 \mathrm{~m}$ altitude, which is the same as was determined for nearby Radovna River valley [35].

The estimated recharge altitude of thermal water was between 1282-1620 m a.s.l., which is similar to the fresh groundwater springs discharging from Pokljuka. The average recharge altitudes for springs in the Radovna River valley $[33,35]$ were in good agreement with our estimates. High recharge altitudes can also be observed in the case of Mmu-1, V-VP, and V-FD. Mmu-1 is drilled in a fissured dolomite aquifer which extends towards the Pokljuka plateau. The piezometers V-VP and V-FD are drilled in a Quaternary aquifer, which is not directly connected to Pokljuka. It is most likely that the fresh groundwater from the Pokljuka plateau is flowing towards Lake Bled, which represents the local topographic minima. Since the lake bottom has very low hydraulic conductivity due to lacustrine lake-bottom silt and clay, the groundwater discharge zone is limited to a small area at the east lake coast where a Quaternary aquifer is hydraulically connected to dolomite layers with thermal water. Other sampling locations in Quaternary sediments indicate significantly lower recharge altitudes. 


\subsection{Residence Time}

Fresh water and thermal water retention time and mixing ratios were analyzed using tritium values. The lowest tritium activity can be observed in wells V-FD, V-VP (<0.2 TU), and Mmu-1 (1.4 TU) (Figure 12). It is a result of the aquifer structure, where the flow of groundwater is very slow and consequently groundwater has long retention time. The values between 2.07-3.41 TU for thermal water were higher than expected. That means that the thermal water is either flowing quite fast, or a more possible hypothesis is that the mixing with fresh and recent water is more and more intensive and influences the tritium activity. The latter, however, is more likely since there was an upward trend detected in tritium activity within the national monitoring results. All other samples were above $4 \mathrm{TU}$ and can be classified as modern waters (4.1-6.5 TU). The TDS-tritium (Figure 12) graph confirms the existence of different origins. High tritium and low TDS values indicated fast and shallow circulation, while low tritium values and high TDS indicated longer and deep circulations. A longer retention time was also related to low permeability and long flow paths in the recharge area. The B-tritium relationship can also be used to separate between shallow- and deep-water circulation.
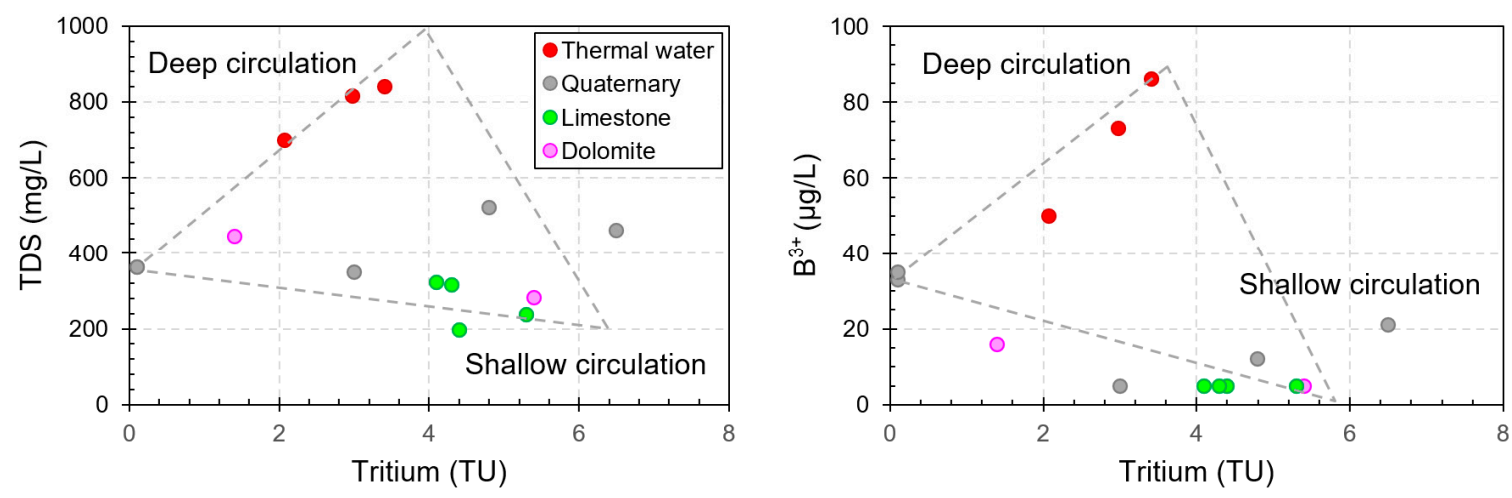

Figure 12. Tritium vs. TDS (left figure) and tritium vs. $\mathrm{B}^{3+}$ (right figure).

\section{Discussion}

Based on chemical and isotopic data, we interpreted that three major flow patterns of groundwater fluxes can be observed in the Bled area. They can be correlated with the concept of the regional groundwater flow [67]. In the small-scale mountain catchments, springs or groundwater wells that drain different flow systems can occur in close contact to each other $[68,69]$. Here, the first pattern is represented by subsurface runoff at the dominated groundwater level scale, which is characterized by very short residence time and shallow pathways (up to few $10 \mathrm{~m}$ ). The second pattern is represented by shallow hillslope scale groundwater fluxes with slow to moderate retention time and shallower groundwater flow (up to few $100 \mathrm{~m}$ ). The last pattern is determined by geothermal aquifer and characterized by larger transit times, and deeper pathways which can bypass the seepage boundaries as rivers and lakes.

The processes in surface water, fresh groundwater, and thermal water are dominated by the dissolution of calcite and dolomite, corresponding to the observed limestone and dolomite in the recharge area. This indicates that the predominant process is carbonate weathering [70]. The major ions in fresh groundwater springs reveal that the carbonaceous drainage basin is mostly unpolluted. The same conclusion can also be accepted for thermal water since the values of $\mathrm{NO}_{3}{ }^{-}$in thermal water are below the LOD $(<2.2 \mathrm{mg} / \mathrm{L})$.

The isotopic composition of $\delta^{18} \mathrm{O}$ and $\delta^{2} \mathrm{H}$ in water confirms that the thermal water in Bled is of meteoric origin being infiltrated at relatively high altitudes (up to $1620 \mathrm{~m}$ ). The karstic plateau allows the water to flow into a deeper permeable zone where it is heated by thermal conduction involving geothermal gradient of only approx. $1^{\circ} \mathrm{C} / 100 \mathrm{~m}$. It is also possible that the values of $\delta^{18} \mathrm{O}$ and $\delta^{2} \mathrm{H}$ are related to different climate conditions during meteoric water infiltration. If such a scenario existed, 
the residence time should be longer as measured by tritium activity in thermal water. Still, the higher temperature in the shallow system (thermal spring zone) is not attributed to a heat flow anomaly but related to a natural outflow of a deep flow of heated meteoric water, which is typical for the Alps $[7,9,11]$ and other similar systems around the world.

Relatively high tritium values in thermal water refer to possible mixing processes between the deep thermal component and fresh shallow groundwater. The latter was also confirmed with some chemical element $\left(\mathrm{Cl}^{-}, \mathrm{Sr}^{2+}, \mathrm{B}^{3+}, \mathrm{Ba}^{2+}\right)$ correlations. Two scenarios were identified: (1) Mixing of recent groundwater in tritium-free thermal water in the shallow part of the primary geothermal reservoir; and (2) mixing in a secondary geothermal reservoir within glaciofluvial sediments (Figure 13).

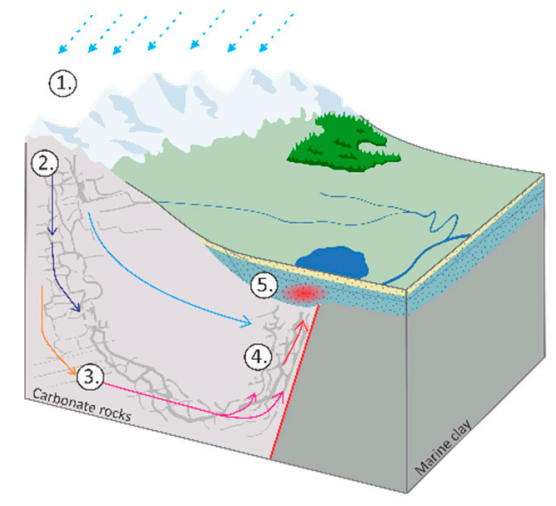

Figure 13. Conceptual model of the Bled area: (1) Precipitation and recharge, (2) infiltration, (3) regional groundwater flow with higher temperature and pressure in deep layers, (4) thermal water uplift, and (5) fresh groundwater and thermal water mixing in Quaternary sediments, resulting in emergence of thermal plume.

\section{Conclusions}

Thermal outflow in Bled is determined by the presence of deeper water circulation system where the dissolution of calcite and dolomite is the main hydrochemical process affecting chemical components of natural groundwater flow. The isotopic composition of oxygen and deuterium in water confirms that thermal water is recharging from altitudes up to $1620 \mathrm{~m}$.

Microelements, especially tritium activity in thermal water, indicate the presence of intensive mixing processes in the shallow part of the primary geothermal aquifer, as well as in the secondary geothermal aquifer. The mixing processes between fresh groundwater and thermal water take place in both the shallow zone of the karstic-fissured aquifer where the fluid is uprising, and in the Quaternary sediments where the mixing is reflected in the emergence of a thermal plume extending at the east lake coast. The latter is suggested both by major ions and microelements in groundwater, as their concentration decreases with the distance from the thermal outflow cone.

Both chemical and isotopic composition and its spatial distribution indicate the presence of groundwater fluxes with short and shallow pathways within the shallow fresh groundwater flow, while the thermal water flow in the karstic-fissured aquifer can be characterized by larger transit times and deeper pathways which are naturally discharging due to geological boundaries.

By applying various hydrogeochemical methods, we can confirm the assumption that the thermal water is recharging with meteoric infiltration and water flow through thick layers of limestone and dolomite rocks forming the Pokljuka plateau. Moreover, the possible existence of mixing processes between thermal water and shallow fresh groundwater can be confirmed.

The hydrogeochemical approach applied in this research has proved to be very useful in order to implement the hydrogeological conceptual model of this pronounced Alpine water circulation system. The latter will be used to set the proper boundary condition for hydrogeological and geothermal modeling. 
Still, the highest uncertainty is related to recharge characteristics of thermal water (e.g., mean residence time). In order to better understand mixing processes and to identify possible seasonal patterns, future research will be focused on more intensive measurements of stable isotopes in water $\left(\delta^{18} \mathrm{O}\right.$ and $\left.\delta^{2} \mathrm{H}\right)$.

Author Contributions: Conceptualization and methodology, L.S., N.R., and M.B.; software and data analysis, L.S.; writing the manuscript—original draft preparation, L.S.; writing—review and editing, L.S., M.B., and N.R.; supervision, M.B. and N.R.; project administration, N.R. All authors have read and agreed to the published version of the manuscript.

Funding: The paper was prepared under the PhD Grant 1000-19-0215 at the Geological Survey of Slovenia, and financed by the Slovenian Research Agency (ARRS) through the research program P1-0020 Groundwater and Geochemistry in the frame of the Young Researchers Programme.

Acknowledgments: Authors greatly acknowledge the permission of Sava Turizem d.d. to use monitoring data.

Conflicts of Interest: The authors declare no conflict of interest.

\section{References}

1. Gleeson, T.; Manning, A.H. Regional groundwater flow in mountainous terrain: Three-dimensional simulations of topographic and hydrogeologic controls. Water Resour. Res. 2008, 44, W10403. [CrossRef]

2. Garven, G. Continental-scale groundwater flow and geologic processes. Annu. Rev. Earth Planet. Sci. 1995, 23, 89-118. [CrossRef]

3. Cao, G.L.; Han, D.M.; Currell, M.J.; Zheng, C.M. Revised conceptualization of the North China Basin groundwater flow system: Groundwater age, heat and flow simulations. J. Asian Earth Sci. 2016, 127, 119-136. [CrossRef]

4. Bowen, R. Geothermal Resources, 2nd ed.; Elsevier Applied Science: London, UK, 1989; p. 485.

5. Hochstein, P.M. Assessment and Modelling of Geothermal Reservoirs (Small Utilization Schemes). Geothermics 1988, 17, 15-49. [CrossRef]

6. Sonney, R. Groundwater Flow, Heat and Mass Transport in Geothermal Systems of a Central Alpine Massif. The Cases of Lavey-Les-Bains, Saint-Gervais-Les-Bains and Val d'Illiez. Ph.D. Thesis, University of Neuchâtel, Neuchâtel, Switzerland, 2010.

7. Rybach, L. Slowly moving thermal/mineral waters in deep crystalline basement. Environ. Geol. 2009, 58, 1645-1651. [CrossRef]

8. Rybach, L.; Eugster, W.; Griesser, J.C. Die geothermischen Verhältnisse in der Nordschweiz. Eclogae Geol. Helv. 1987, 80, 531-534.

9. Bianchetti, G.; Roth, P.; Vuataz, F.D.; Vergain, J. Deep groundwater circulation in the Alps: Relations between water infiltration, induced seismicity and thermal springs. The case of Val d'Illiez, Wallis. Eclogae Geol. Helv. 1992, 85, 291-305.

10. Sonney, R.; Vuataz, F.D. Properties of geothermal fluids in Switzerland: A new interactive database. Geothermics 2008, 37, 496-509. [CrossRef]

11. Sonney, R.; Vuataz, F.D. Numerical modelling of Alpine deep flow systems: A manegement and prediction tool for an exploited geothermal reservoir (Lavey-les-Bains, Switzerland). Hydrogeol. J. 2009, 17, 601-616. [CrossRef]

12. Petrini, R.; Italiano, F.; Ponton, M.; Slejko, F.F.; Aviani, U.; Zini, L. Geochemistry and isotope geochemistry of the Monfalcone thermal waters (northern Italy): Inference on the deep geothermal reservoir. Hydrogeol. J. 2013, 21, 1275-1287. [CrossRef]

13. Lapanje, A.; Rman, N. Thermal and thermomineral water. In The Geology of Slovenia; Pleničar, M., Ogorelec, B., Novak, M., Eds.; Geological Survey of Slovenia: Ljubljana, Slovenia, 2009; pp. 553-560.

14. Lapanje, A. Izvor in kemijska sestava termnalnih in termomineralnih vod v Sloveniji. (Origin and chemical composition of thermal and thermomineral waters in Slovenia). Geologija 2006, 49, 347-370. [CrossRef]

15. Zmazek, B.; Italiano, F.; Živčić, M.; Vaupotič, J.; Kobal, I.; Martinelli, G. Geochemical monitoring of thermal waters in Slovenia: Relationships to seismic activity. Appl. Radiat. Isot. 2002, 57, 919-930. [CrossRef]

16. Zmazek, B.; Todorovski, L.; Živčić, M.; Džeroski, J.; Vaupotič, J.; Kobal, I. Radon in a thermal spring: Identification of anomalies related to seismic activity. Appl. Radiat. Isot. 2005, 64, 725-734. [CrossRef] [PubMed] 
17. Philipp, S. Hydrochemistry and Isotopic Analysis of Deep (Partly Thermal) Wells and Springs in NW-Slovenia. Ph.D. Thesis, Technische Universität Darmstadt, Darmstadt, Germany, 2015.

18. Arnórsson, S.; Stefánsson, A.; Bjarnason, J. Fluid-fluid interaction in geothermal systems. Rev. Mineral. Geochem. 2007, 65, 259-312. [CrossRef]

19. Zhang, Y.; Xu, M.; Li, X.; Qi, J.; Zhang, Q.; Guo, J.; Yu, L.; Zhao, R. Hydrochemical characteristics and multivariate statistical analysis of natural water system: A case study in Kangding County, Southwestern China. Water 2018, 10, 80. [CrossRef]

20. Qiu, X.; Wang, Y.; Wang, Z.; Regenauer-Lieb, K.; Zhang, K.; Liu, J. Determining the origin, circulation path and residence time of geothermal groundwater using multiple isotopic techniques in the Heyuan Fault Zone of Southern China. J. Hydrol. 2008, 567, 339-350. [CrossRef]

21. Arnórsson, S. Geothermal systems in Iceland: Structure and conceptual models I. High-temperature areas. Geothermics 1995, 24, 561-602.

22. Hilberg, S. Review: Natural tracers in fractured hard-rock aquifers in the Austrian part of the Eastern Alps-previous approaches and future perspectives for hydrogeology in mountain regions. Hydrogeol. J. 2016, 24, 1091-1105. [CrossRef]

23. Michard, G. Behaviour of major elements and some trace elements (Li, Rb, Cs, Sr, Fe, Mn, W, F) in deep hot waters from granitic areas. Chem. Geol. 1990, 89, 117-134. [CrossRef]

24. Rman, N. Hydrogeochemical and isotopic tracers for identification of seasonal and long-term over-exploitation of the Pleistocene thermal waters. Environ. Monit. Assess. 2016, 188, 242-262. [CrossRef]

25. Clark, I.; Fritz, P. Environmental Isotopes in Hydrogeology; CRC Press: New York, NY, USA, 1997; p. 328.

26. Calligaris, C.; Mezga, K.; Slejko, F.F.; Urbanc, J.; Zini, L. Groundwater Characterization by Means of Conservative $\left(\delta^{18} \mathrm{O}\right.$ and $\left.\delta^{2} \mathrm{H}\right)$ and Non-Conservative $\left({ }^{87} \mathrm{Sr} /{ }^{86} \mathrm{Sr}\right)$ Isotopic Values: The Classical Karst Region Aquifer Case (Italy-Slovenia). Geoscience 2018, 8, 321. [CrossRef]

27. Szőcs, T.; Rman, N.; Süveges, M.; Palcsu, L.; Tóth, G.; Lapanje, A. The application of isotope and chemical analyses in managing transboundary groundwater resources. Appl. Geochem. 2013, 32, 95-107.

28. Zega, M.; Rožič, B.; Gaberšek, M.; Kanduč, T.; Žvab Rožič, P.; Verbovšek, T. Mineralogical, hydrogeochemical and isotopic characteristics of the Žveplenica sulphide karstic spring (Trebuša Valley, NW Slovenia). Environ. Earth Sci. 2015, 74, 3287-3300. [CrossRef]

29. Rman, N.; Lapanje, A.; Szőcs, T.; Palcsu, L.; Junež, P. Origin of high mineralized mineral water and gas in Rogaška slatina, Slovenia. In Proceedings of the 2nd International Interdisciplinary Conference on Mineral Waters, Vila de Luso, Portugal, 26-31 March 2017.

30. Brenčič, M. Hydrogeochemistry of Coastal Carbonate Aquifer in Lucij-Portorož (Gulf of Trieste, Northern Adriatic Sea, Slovenia). Acta Carsologica 2009, 38, 179-196.

31. Cerar, S.; Urbanc, J. Carbonate chemistry and isotope characteristics of groundwater of Ljubljansko Polje and Ljubljansko Barje aquifers in Slovenia. Sci. World J. 2013, 2013, 948394. [CrossRef]

32. Mezga, K. Natural Hydrochemical Background and Dynamics of Groundwater in Slovenia. Ph.D. Thesis, University of Nova Gorica, Nova Gorica, Slovenia, 2014.

33. Kanduč, T.; Mori, N.; Kocman, D.; Stibilj, V.; Grassa, F. Hydrogeochemistry of Alpine springs from North Slovenia: Insights from stable isotopes. Chem. Geol. 2012, 300-301, 40-54. [CrossRef]

34. Verbovšek, T.; Kanduč, T. Isotope Geochemistry of Groundwater from Fractured Dolomite Aquifers in Central Slovenia. Aquat. Geochem. 2015, 22, 131-151. [CrossRef]

35. Torkar, A.; Brenčič, M.; Vreča, P. Chemical and isotopic characteristics of groundwater-dominated Radovna River (NW Slovenia). Environ. Earth Sci. 2016, 75, 1296-1314. [CrossRef]

36. Torkar, A.; Brenčič, M. Spatio-temporal distribution of discharges in the Radovna River valley at low water conditions. Geologija 2015, 58, 47-56. [CrossRef]

37. Archive of Weather Observations. Slovenian Environment Agency. Available online: http://meteo.arso.gov.si (accessed on 18 March 2019).

38. Buser, S. Osnovna Geološka Karta SFRJ 1: 100.000. Tolmač Lista Celovec (Klagenfurt); Zvezni GeološKi Zavod: Beograd, Serbia, 1980; p. 62.

39. Buser, S. Osnovna Geološka Karta SFRJ 1: 100.000. Tolmač Listov Tolmin in Videm (Udine); Zvezi GeološKi Zavod: Beograd, Serbia, 1986; p. 103.

40. Jurkovšek, B. Osnovna Geološka Karta SFRJ. 1:100.000. Tolmač Listov Beljak in Ponteba; Zvezni GeološKi Zavod: Beograd, Serbia, 1987; p. 58. 
41. Goričan, Š.; Žibret, L.; Košir, A.; Kukoč, D.; Horvat, A. Stratigraphic correlation and structural position of Lower Cretaceous flysch-type deposits in the eastern Southern Alps (NW Slovenia). Int. J. Earth Sci. 2018, 107, 2933-2953. [CrossRef]

42. Gale, L.; Kolar-Jurkovšek, T.; Karničnik, B.; Celarc, B.; Goričan, Š.; Rožič, B. Triassic deep-water sedimentation in the Bled Basin, eastern Julian Alps, Slovenia. Geologija 2019, 62, 153-173. [CrossRef]

43. Placer, L. Contribution to the macrotectonic subdivision of the border region between Southern Alps and External Dinarides. Geologija 1999, 41, 223-255. [CrossRef]

44. Bavec, M.; Verbič, T. The extent of Quaternary glaciations in Slovenia. In Developments in Quaternary Science; Ehlers, J., Gibbard, P.L., Eds.; Elsevier Science: Amsterdam, The Netherlands, 2004; Volume 2, pp. 385-388.

45. Serianz, L. Tri-dimensional Model of the Radovna Glacier from Last Glacial Period. Geologija 2016, 59, 193-204. [CrossRef]

46. Lapanje, A.; Budkovič, T.; Rikanovič, R.; Rajver, D.; Rman, N.; Matoz, T. Hidrogeološke Strokovne Osnove za Izkoriščanje Termalne vode na Bledu; Geological Survey of Slovenia: Ljubljana, Slovenia, 2009.

47. Kazemi, G.A.; Lehr, J.H.; Perrochet, P. Groundwater Age; John Wiley \& Sons: Hoboken, NJ, USA, 2006.

48. National Monitoring of Chemical Status. Slovenian Environment Agency. Available online: http://www.arso. gov.si/vode (accessed on 10 January 2019).

49. Croghan, C.W.; Egeghy, P.P. Methods of dealing with values below the limit of detection using SAS. In Proceedings of the Southeastern SAS User Group, St. Petersburg, FL, USA, 22-24 September 2003; Environmental Protection Agency: Washington, DC, USA, 2003.

50. Piper, A.M. A graphic procedure in the geochemical interpretation of water-analyses. Eos Trans. Am. Geophys. Union 1944, 25, 914-928. [CrossRef]

51. Gibbs, R.J. Mechanisms controlling world water chemistry. Science 1970, 170, 1088-1090. [CrossRef]

52. Marandi, A.; Shand, P. Groundwater chemistry and the Gibbs Diagram. Appl. Geochem. 2018, 97, $209-212$. [CrossRef]

53. Mayo, L.; Loucks, M.D. Solute and isotopic geochemistry and ground water flow in the central Wasatch Range, Utah. J. Hydrol. 1995, 172, 31-59. [CrossRef]

54. López-Chicano, M.; Bouamama, M.; Vallejos, A.; Pulido-Bosch, A. Factors which determine the hydrogeochemical behaviour of karstic springs. A case study from the Betic Cordilleras, Spain. Appl. Geochem. 2001, 16, 1179-1192.

55. Argamasilla, M.; Barbera, J.A.; Andreo, B. Factors controlling groundwater salinization and hydrogeochemical processes in coastal aquifers from southern Spain. Sci. Total Environ. 2017, 580, 50-68. [CrossRef]

56. Wickham, H.; François, R.; Henry, L.; Kirill, M. CRAN-Package 'dplyr', A Grammar of Data Manipulation. Available online: https://cran.r-project.org/web/packages/dplyr/dplyr.pdf (accessed on 15 July 2018).

57. R Development Core Team. R: A Language and Environment for Statistical Computing; R Foundation for Statistical Computing Vienna: Vienna, Austria, 2018.

58. Krajcar Bronič, I.; Barešić, J.; Borković, D.; Sironić, A.; Mikelić Lovrenčić, I.; Vreča, P. Long-Term Isotope Records of Precipitation in Zagreb, Croatia. Water 2020, 12, 226. [CrossRef]

59. Craig, H. Isotope variations in meteoric waters. Science 1961, 133, 1702-1703. [CrossRef]

60. Vreča, P.; Krajcar Bronič, I.; Leis, A.; Brenčič, M. Isotopic composition of precipitation in Ljubljana (Slovenia). Geologija 2008, 51, 169-180. [CrossRef]

61. Gat, J.R.; Carmi, I. Evolution of the isotopic composition of atmospheric waters in the Mediterranean Sea area. J. Geophys. Res. 1970, 75, 3039-3048. [CrossRef]

62. Giustini, F.; Brilli, M.; Patera, A. Mapping oxygen stable isotopes of precipitation in Italy. J. Hydrol. Reg. Stud. 2016, 8, 162-181. [CrossRef]

63. Jasechko, S. Partitioning young and old groundwater with geochemical tracers. Chem. Geol. 2016, 427, 35-42. [CrossRef]

64. Vreča, P.; Krajcar Bronič, I.; Leis, A.; Demšar, M. Isotopic composition of precipitation at the station Ljubljana (Reaktor), Slovenia-period 2007-2010. Geologija 2014, 57, 217-230. [CrossRef]

65. Rman, N. Uporabnost ionskih geotermometrov na slovenskih termalnih vodah = Applicability of ionic geothermometers on Slovene thermal waters. In Proceedings of the 19 Posvetovanje Slovenskih Geologov, Ljubljana, Slovenia, 19-26 July 2009.

66. Leibundgut, C.; Maloszewski, P.; Kulls, C. Tracers in hydrology, 1st ed.; John Wiley \& Sons: Hoboken, NJ, USA, 2014. 
67. Tóth, J. A theoretical analysis of groundwater flow in small drainage basins. J. Geophys. Res. 1963, 68, 4795-4812. [CrossRef]

68. Hilberg, S.; Kreuzer, M. Identification of a deep flow system in a dolomitic alpine aquifer: Case study Wimmerbauern spring, Bad Ischl. Aust. J. Earth Sci. 2013, 106, 16-25.

69. Hilberg, S.; Riepler, F. Interaction of various flow systems in small alpine catchments: Conceptual model of the upper Gurk Valley aquifer, Carinthia, Austria. Hydrogeol. J. 2016, 24, 1231-1244. [CrossRef]

70. Meybeck, M. River water quality, global ranges time and space variabilities. Verh. Int. Ver. Limnol. 1996, 26, 81-96.

(C) 2020 by the authors. Licensee MDPI, Basel, Switzerland. This article is an open access article distributed under the terms and conditions of the Creative Commons Attribution (CC BY) license (http://creativecommons.org/licenses/by/4.0/). 